Article

\title{
Multiple Model Predictive Hybrid Feedforward Control of Fuel Cell Power Generation System
}

\author{
Long $\mathrm{Wu}^{1}{ }^{1}$, Li Sun ${ }^{1}{ }^{(\mathbb{D})}$, Jiong Shen ${ }^{1, *}$ and Qingsong Hua ${ }^{2}$ \\ 1 Key Laboratory of Energy Thermal Conversion and Control of Ministry of Education, School of Energy and \\ Environment, Southeast University, Sipailou 2, Nanjing 210096, China; wulong@seu.edu.cn (L.W.); \\ sunli12@seu.edu.cn (L.S.) \\ 2 School of Mechanical and Electrical Engineering, Qingdao University, Ningxia Road 308, \\ Qingdao 266071, China; qihu@qdu.edu.cn \\ * Correspondence: shenj@seu.edu.cn
}

Received: 6 January 2018; Accepted: 4 February 2018; Published: 8 February 2018

\begin{abstract}
Solid oxide fuel cell (SOFC) is widely considered as an alternative solution among the family of the sustainable distributed generation. Its load flexibility enables it adjusting the power output to meet the requirements from power grid balance. Although promising, its control is challenging when faced with load changes, during which the output voltage is required to be maintained as constant and fuel utilization rate kept within a safe range. Moreover, it makes the control even more intractable because of the multivariable coupling and strong nonlinearity within the wide-range operating conditions. To this end, this paper developed a multiple model predictive control strategy for reliable SOFC operation. The resistance load is regarded as a measurable disturbance, which is an input to the model predictive control as feedforward compensation. The coupling is accommodated by the receding horizon optimization. The nonlinearity is mitigated by the multiple linear models, the weighted sum of which serves as the final control execution. The merits of the proposed control structure are demonstrated by the simulation results.
\end{abstract}

Keywords: solid oxide fuel cell; constant output voltage; multiple model predictive control

\section{Introduction}

Since the middle of the 20th century, traditional energy was consumed in large quantities, fossil fuels are growing shortage and the environment has been deteriorated. Nowadays, the society is facing an extremely serious energy and environmental crisis. It is imminent to develop a safe, efficient and clean energy [1]. Fuel cell is an energy tool which uses hydrogen as a raw material and converts its chemical energy directly into electric energy by a certain device. And it has many advantages such as high energy density, low pollution emission, strong ability of adaptation, therefore, fuel cell is becoming a promising substitute for conventional fossil fuel [2-4]. Moreover, fuel cell electricity generation is regarded as the core of the future hydrogen production and utilization industry [5].

Among a variety of fuel cells, solid oxide fuel cell (SOFC) has been a focus in order to implement large-scale power generation because it has simple principle, high efficiency, long-term stability and excellent load flexibility [6-8]. SOFC attracts increasing attention, especially in sustainable generation and power supply field, it is widely considered as one of the effective ways to solve the current energy problems [9-16]. Load flexibility of SOFC is capable of adjusting the power output to meet the requirements from power grid balance. However, there still exist many difficulties which should be conquered to promote practical application and commercialization of SOFC, especially, it is crucial to implement an effective control for SOFC system to maintain output voltage as constant and fuel utilization rate kept within a safe range, so that extends the life of the electric pile, improves the operating efficiency and the power quality of SOFC [17-19]. But its precisely effective control is 
completely difficult because SOFC features the multivariable coupling and nonlinearity within a wide-range operation caused by its electrochemical properties.

Generally, SOFC is composed of cathode, anode and electrolyte between them. The anode gas channel is injected with the certain amount of fuel gas and the cathode is supplied with the appropriate amount of oxidant gas. The two gases continuously pass through the bipolar gas channels severally sat both sides of the electrolyte to react to generate electricity. Usually, hydrogen is as fuel gas and cheap air is as oxidant gas. Based on constant output voltage mode of SOFC, in the practical operation, the outside resistance load demand is met by the use of providing the proper amount of hydrogen and air, meanwhile, it is necessary to keep SOFC constant output voltage [20] and fuel utilization rate within a safe range. The fuel utilization rate is to be the ratio of the amount of hydrogen that generates electrochemical reaction in the SOFC to the amount of hydrogen that is fed into the SOFC, it is an important parameter influencing the performance of SOFC system. The fuel utilization rate is usually required between $0.7 \sim 0.9$, too large or too small, respectively, indicate the amount of hydrogen overused and underused, which may result in SOFC performance drop or permanent damage [21]. Simplified working process of SOFC is illustrated in Figure 1.

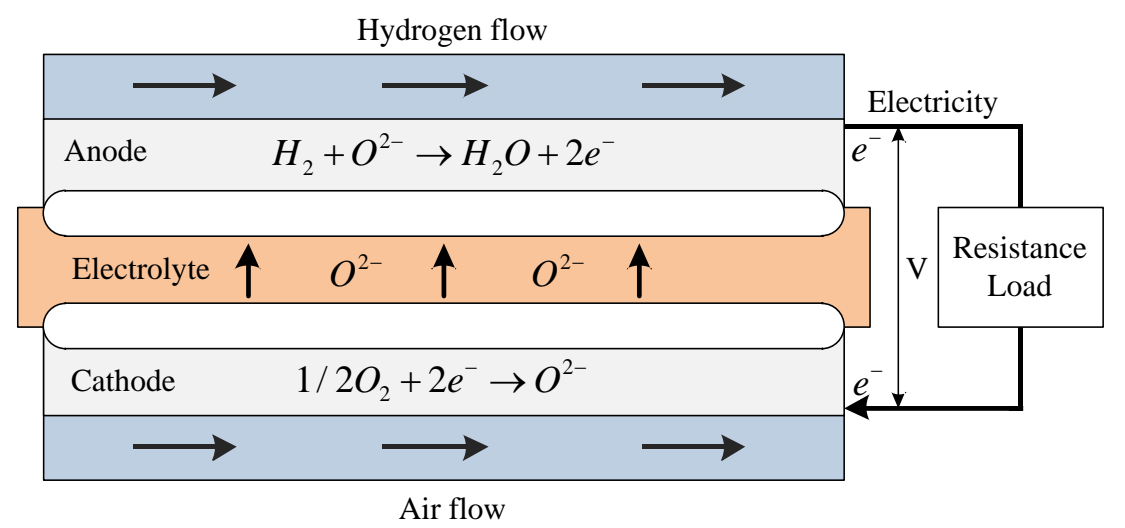

Figure 1. Schematic of the SOFC.

SOFC has strong nonlinearity due to its complicated electrochemical properties, especially when outside resistance load changes in a wide-range, therefore, a single controller is difficult to satisfy the control requirements. And the hydrogen flow rate and air flow rate fed into SOFC are usually constrained in working process, for instance, the limit caused by the performance of fuel blower. To deal with nonlinear problems, multiple model control method is extremely suitable, meanwhile, model predictive control (MPC) can be used to deal with multivariable coupling and constraint problems skillfully.

To overcome the aforementioned difficulties, a multiple model feedforward predictive control (MFPC) is proposed for SOFC system to ensure its reliable operation. In the working range of SOFC, firstly, the different operating points of SOFC are selected to obtain the locally linearized sub models for each operating point of SOFC. Secondly, the global model for the current time is obtained by using the multiple model method, concretely, by the use of the weighted sum of the several sub models and the variation of resistance load is taken as a measurable disturbance that is inputted the multiple model predictive controller as a feedforward compensation. Finally, the multiple model feedforward predictive controller that depends on the receding horizon optimization and correction can be designed to achieve SOFC constant output voltage and fuel utilization rate in a safe range.

\section{Dynamics and Nonlinearity Analysis of SOFC}

A dynamic model of SOFC proposed in [22] is taken account of as the control plant in this paper. In [22], the one-dimensional mathematical model of an SOFC is presented, which considers electrochemical, thermodynamic and fluidic characteristics inside SOFC and presents detailed 
explanations of operating mechanisms and model parameters of SOFC and verifies its dynamic model in MATLAB SIMULINK. The dynamic model of SOFC developed in [22] is widely accepted and cited in research field [23-28]. The dynamic model consists of the diffusion, material conservation parts and the electrochemical, thermodynamic parts, the simplified diagram of the dynamic model of SOFC is illustrated in Figure 2.

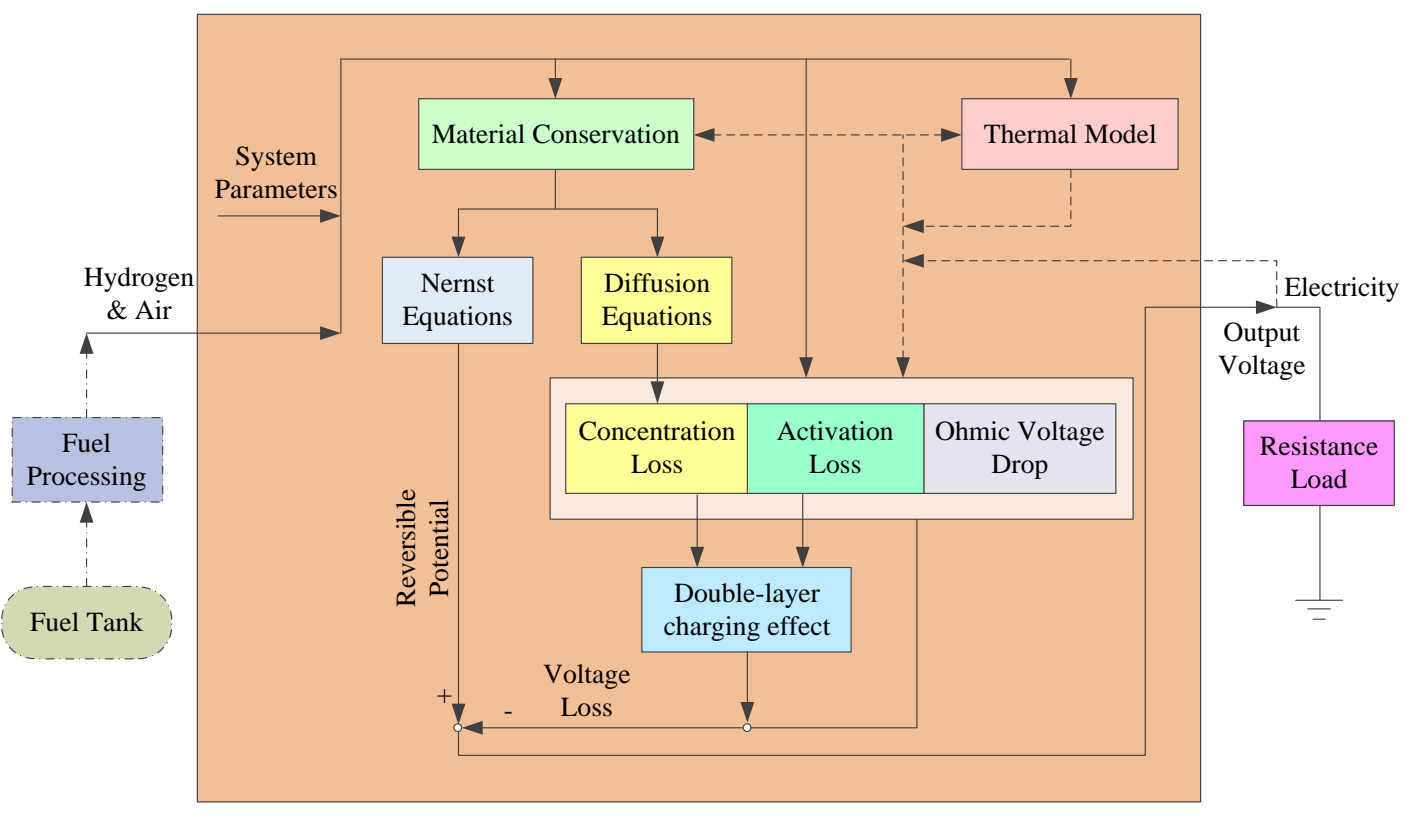

Figure 2. Diagram of the dynamic model of SOFC.

In this dynamic model of SOFC, the Nernst equation is used to determine the reversible potential of the SOFC $\mathrm{E}_{\text {cell }}$ as follows:

$$
\mathrm{E}_{\text {cell }}=\mathrm{E}_{0, \text { cell }}+\frac{\mathrm{R}_{0} \mathrm{~T}}{4 \mathrm{~F}} \ln \frac{\mathrm{p}_{\mathrm{H}_{2}}{ }^{2} \mathrm{p}_{\mathrm{O}_{2}}}{\mathrm{p}_{\mathrm{H}_{2} \mathrm{O}}{ }^{2}}
$$

where $\mathrm{E}_{0, \text { cell }}$ is a temperature function and can be calculated from:

$$
\mathrm{E}_{0, \text { cell }}=\mathrm{E}_{\mathrm{std}, \mathrm{cell}}-\mathrm{k}_{\mathrm{E}}(\mathrm{T}-298)
$$

where $E_{\text {std,cell }}$ is the standard reference potential at standard state $298 \mathrm{~K}$ and $1 \mathrm{~atm}$.

The material conservation is an important part of calculation of SOFC as follows:

$$
\begin{aligned}
\frac{\mathrm{V}_{\mathrm{a}}}{\mathrm{R}_{0} \mathrm{~T}} \frac{\mathrm{dp}_{\mathrm{H}_{2}}}{\mathrm{dt}}=\mathrm{M}_{\mathrm{H}_{2} \text {,in }}-\mathrm{M}_{\mathrm{H}_{2} \text {,out }}-\frac{\mathrm{i}}{2 \mathrm{~F}} \\
\frac{\mathrm{V}_{\mathrm{a}}}{\mathrm{R}_{0} \mathrm{~T}} \frac{\mathrm{dp}_{\mathrm{H}_{2} \mathrm{O}}}{\mathrm{dt}}=\mathrm{M}_{\mathrm{H}_{2} \mathrm{O}, \text { in }}-\mathrm{M}_{\mathrm{H}_{2} \mathrm{O}, \text { out }}+\frac{\mathrm{i}}{2 \mathrm{~F}} \\
\frac{\mathrm{V}_{\mathrm{c}}}{\mathrm{R}_{0} \mathrm{~T}} \frac{\mathrm{dp}_{\mathrm{O}_{2}}}{\mathrm{dt}}=\mathrm{M}_{\mathrm{O}_{2} \text {,in }}-\mathrm{M}_{\mathrm{O}_{2} \text {,out }}-\frac{\mathrm{i}}{4 \mathrm{~F}}
\end{aligned}
$$

Considering the activation voltage drop, ohmic voltage drop, concentration voltage drop and the double-layer charging effect, the terminal output voltage of the SOFC $V_{\text {cell }}$ is computed as follows:

$$
\mathrm{V}_{\text {cell }}=\mathrm{E}_{\text {cell }}-\mathrm{V}_{\mathrm{C}, \text { cell }}-\mathrm{V}_{\text {act,cell }}-\mathrm{V}_{\text {ohm,cell }}
$$

where $\mathrm{V}_{\mathrm{C} \text {,cell }}$ represents the voltage drop including the double-layer charging effect and the concentration voltage drop and the part of activation voltage drop affected by current, $\mathrm{V}_{\text {act,cell }}$ 
represents the part of activation voltage drop affected by the SOFC internal temperature, $\mathrm{V}_{\text {ohm, cell }}$ represents the ohmic voltage drop and:

$$
\begin{gathered}
\mathrm{V}_{\mathrm{C}, \text { cell }}=\left(\mathrm{i}-\mathrm{C} \frac{\mathrm{dV_{C, \text {cell } }}}{\mathrm{dt}}\right)\left(\mathrm{R}_{\text {act,cell }}+\mathrm{R}_{\text {conc,cell }}\right) \\
\mathrm{V}_{\text {act,cell }}=\xi_{0}+\xi_{1} \mathrm{~T} \\
\mathrm{~V}_{\text {ohm,cell }}=\mathrm{V}_{\text {ohm,elecyt }}+\mathrm{V}_{\text {ohm,inerc }}=i R_{\text {ohm,cell }}
\end{gathered}
$$

The symbols of the SOFC system mentioned in the Equations (1)-(9) are illustrated in Table 1.

Table 1. Symbols in the SOFC system.

\begin{tabular}{ccc}
\hline Parameter & Representation & Unit \\
\hline $\mathrm{R}_{0}$ & Gas constant & $\mathrm{J} /(\mathrm{mol} \cdot \mathrm{K})$ \\
$\mathrm{T}$ & SOFC internal temperature & $\mathrm{K}$ \\
$\mathrm{F}$ & Faraday constant & $\mathrm{C} / \mathrm{mol}$ \\
$\mathrm{p}_{\mathrm{H}_{2}}$ & Hydrogen partial pressure & $\mathrm{Pa}$ \\
$\mathrm{P}_{\mathrm{O}_{2}}$ & Oxygen partial pressure & $\mathrm{Pa}$ \\
$\mathrm{P}_{\mathrm{H}_{2} \mathrm{O}}$ & Water vapor partial pressure & $\mathrm{Pa}$ \\
$\mathrm{k}_{\mathrm{E}}$ & Empirical constant & $\mathrm{V} / \mathrm{K}$ \\
$\mathrm{V}_{\mathrm{a}}$ & Anode channel volume & $\mathrm{m} 3$ \\
$\mathrm{t}$ & Time & $\mathrm{s}$ \\
$\mathrm{M}_{\mathrm{H}_{2} \text {,in }}$ & Hydrogen flow rate of inlet & $\mathrm{mol} / \mathrm{s}$ \\
$\mathrm{M}_{\mathrm{H}_{2, \text { out }}}$ & Hydrogen flow rate of outlet & $\mathrm{mol} / \mathrm{s}$ \\
$\mathrm{i}^{3}$ & Current & $\mathrm{A}$ \\
$\mathrm{M}_{\mathrm{H}_{2} \mathrm{O} \text {,in }}$ & Water flow rate of inlet & $\mathrm{mol} / \mathrm{s}$ \\
$\mathrm{M}_{\mathrm{H}_{2}, \text { out }}$ & Water flow rate of outlet & $\mathrm{mol} / \mathrm{s}$ \\
$\mathrm{V}_{\mathrm{c}}$ & Cathode channel volume & $\mathrm{m}$ \\
$\mathrm{M}_{\mathrm{O}_{2} \text {,in }}$ & Oxygen flow rate of inlet & $\mathrm{mol} / \mathrm{s}$ \\
$\mathrm{M}_{\mathrm{O}_{2, \text { out }}}$ & Oxygen flow rate of outlet & $\mathrm{mol} / \mathrm{s}$ \\
$\mathrm{C}$ & Equivalent capacitance of the double-layer charging effect & $\mathrm{F}$ \\
$\mathrm{R}_{\text {act,cell }}$ & Equivalent resistance of activation voltage drop & $\Omega$ \\
$\mathrm{R}_{\text {conc,cell }}$ & Equivalent resistance of concentration voltage drop & $\Omega$ \\
$\xi_{0}$ & Constant term of activation voltage drop & $\mathrm{\Omega}$ \\
$\xi_{1}$ & Temperature coefficient & $\mathrm{V}$ \\
$\mathrm{R}_{\text {ohm,cell }}$ & Equivalent resistance of ohmic voltage drop & $\mathrm{V} / \mathrm{K}$ \\
$\mathrm{V}_{\text {ohm,elecyt }}$ & Ohmic voltage drop of electrolyte & $\Omega$ \\
$\mathrm{V}_{\text {ohm,inerc }}$ & Ohmic voltage drop of interconnection & $\mathrm{V}$ \\
\hline & & $\mathrm{V}$ \\
\hline
\end{tabular}

In this paper, as aforementioned, the dynamic model of SOFC presented in [22] is taken as the control plant, for the SOFC system, the manipulated variables are hydrogen flow rate and air flow rate, the output variables are output voltage and fuel utilization rate and it is required that the rated output voltage is $140 \mathrm{~V}$ and fuel utilization rate is between $0.7 \sim 0.9$, when resistance load that is considered a measurable disturbance is change. Because the SOFC power is limited to about $5.5 \mathrm{KW}$ in [22], therefore, $140 \mathrm{~V}$ is chosen as the rated output voltage having more practical application value. We reproduce the dynamic model of SOFC referenced from [22] and construct the test model of SOFC system by MATLAB SIMULINK and then some typical steady-state operating points of the SOFC system are selected in the resistance load range 3.4 4.1 $\Omega$, they are shown in Table 2. In addition, the influence of fuel processing is discussed in Section 4.3. 
Table 2. Typical steady-state operating points of the SOFC.

\begin{tabular}{cccccc}
\hline $\begin{array}{c}\text { Operating } \\
\text { Point }\end{array}$ & $\begin{array}{c}\text { Resistance } \\
\text { Load }(\boldsymbol{\Omega})\end{array}$ & $\begin{array}{c}\text { Hydrogen Flow Rate } \\
\left(\mathbf{1 0}^{-\mathbf{4}} \mathbf{~} \mathbf{m o l} / \mathbf{s}\right)\end{array}$ & $\begin{array}{c}\text { Air Flow Rate } \\
\left(\mathbf{1 0}^{-\mathbf{3}} \mathbf{~} \mathbf{m o l} / \mathbf{s}\right)\end{array}$ & $\begin{array}{c}\text { Output } \\
\text { Voltage }(\mathbf{V})\end{array}$ & $\begin{array}{c}\text { Fuel Utilization } \\
\text { Rate }\end{array}$ \\
\hline $1 \#$ & 3.4 & 2.667 & 9.5 & 140 & 0.8 \\
$2 \#$ & 3.6 & 2.520 & 13.5 & 140 & 0.8 \\
$3 \#$ & 3.8 & 2.386 & 22.3 & 140 & 0.8 \\
$4 \#$ & 4.0 & 2.267 & 55.0 & 140 & 0.8 \\
$5 \#$ & 4.1 & 2.211 & 165.0 & 140 & 0.8 \\
\hline
\end{tabular}

Dynamics and nonlinearity of the SOFC are investigated by step change response tests at operating points 1\#, 2\#, 3\#, 5\# in MATLAB/SIMULINK on condition that the SOFC is in the open-loop. The tests include $0.2 \Omega$ step increase of resistance load, $0.2 \times 10^{-4} \mathrm{~mol} / \mathrm{s}$ step increase of hydrogen flow rate and $10 \times 10^{-3} \mathrm{~mol} / \mathrm{s}$ step increase of air flow rate, respectively. The response tests are shown in Figures 3-5. The results demonstrate that resistance load and hydrogen flow rate step increase can change output voltage and fuel utilization rate quickly and can cause output voltage rise rapidly and fuel utilization rate drop fleetly. Meanwhile, it is to interest to note that output voltage and fuel utilization rate both slowly descend and the SOFC take more than $3000 \mathrm{~s}$ to reach a new steady-state, when the air flow rate increase occurs. Besides this, it is also revealed that the SOFC has different step response characteristics at different operating points, therefore the SOFC has obvious nonlinearity.

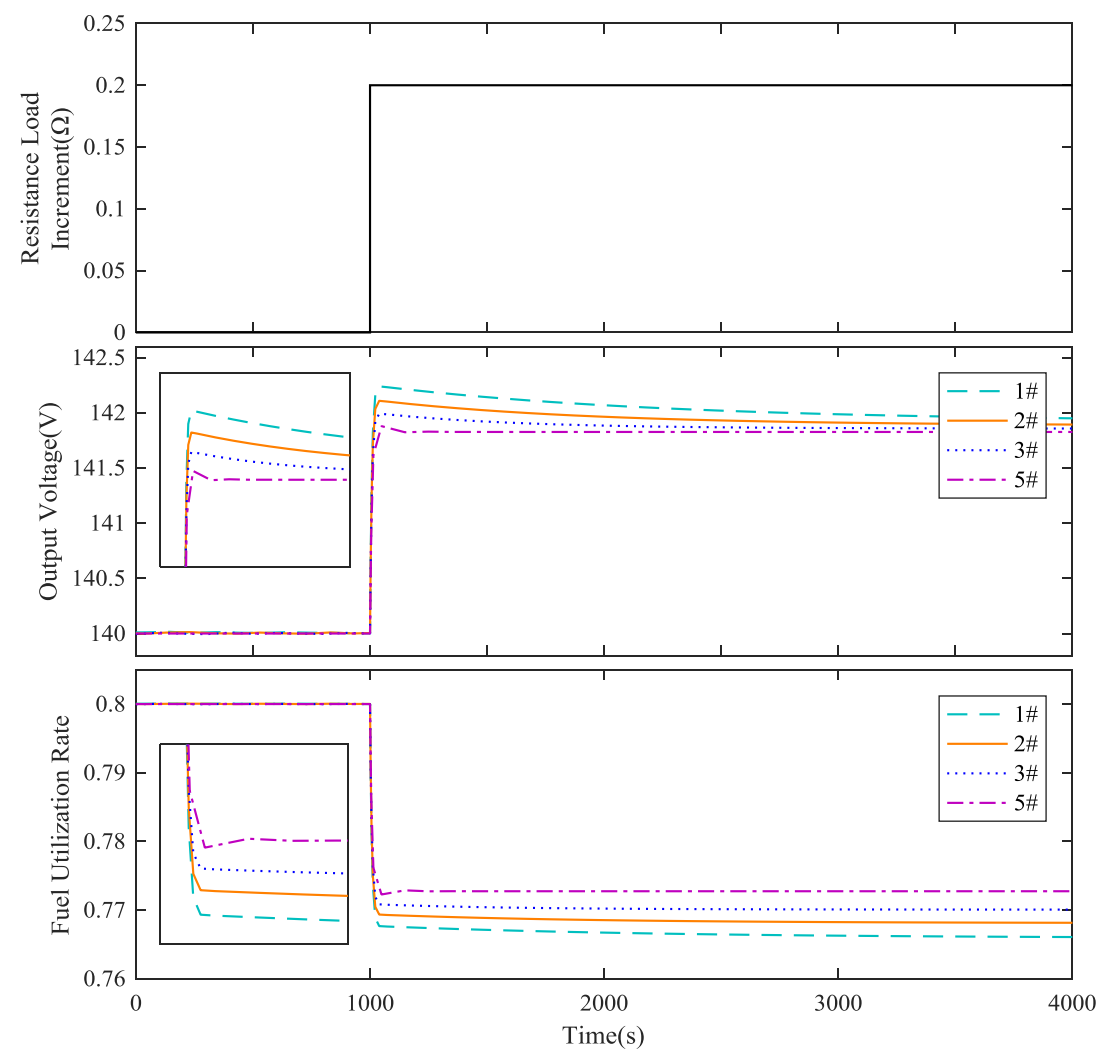

Figure 3. Step response of the SOFC: $0.2 \Omega$ step increase of resistance load. 


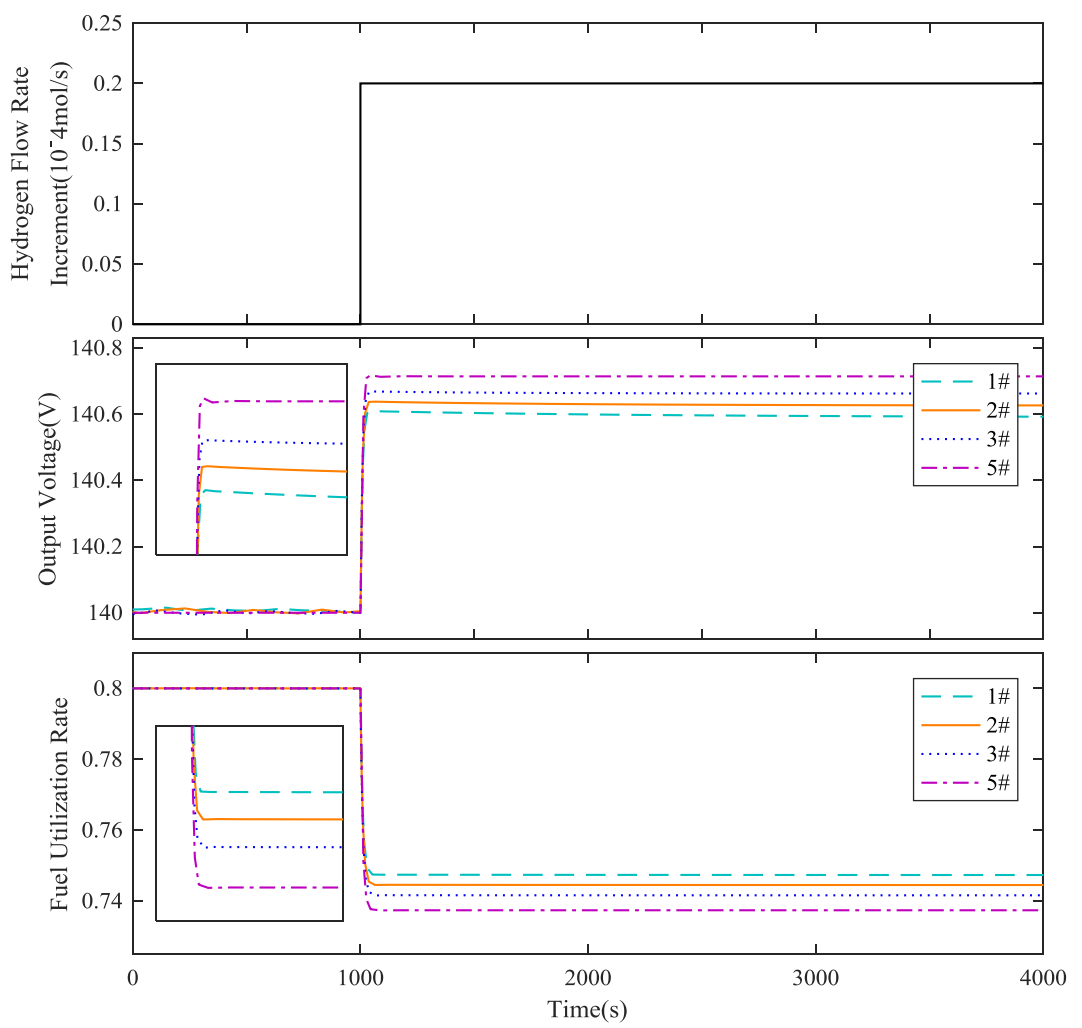

Figure 4. Step response of the SOFC: $0.2 \times 10^{-4} \mathrm{~mol} / \mathrm{s}$ step increase of hydrogen flow rate.

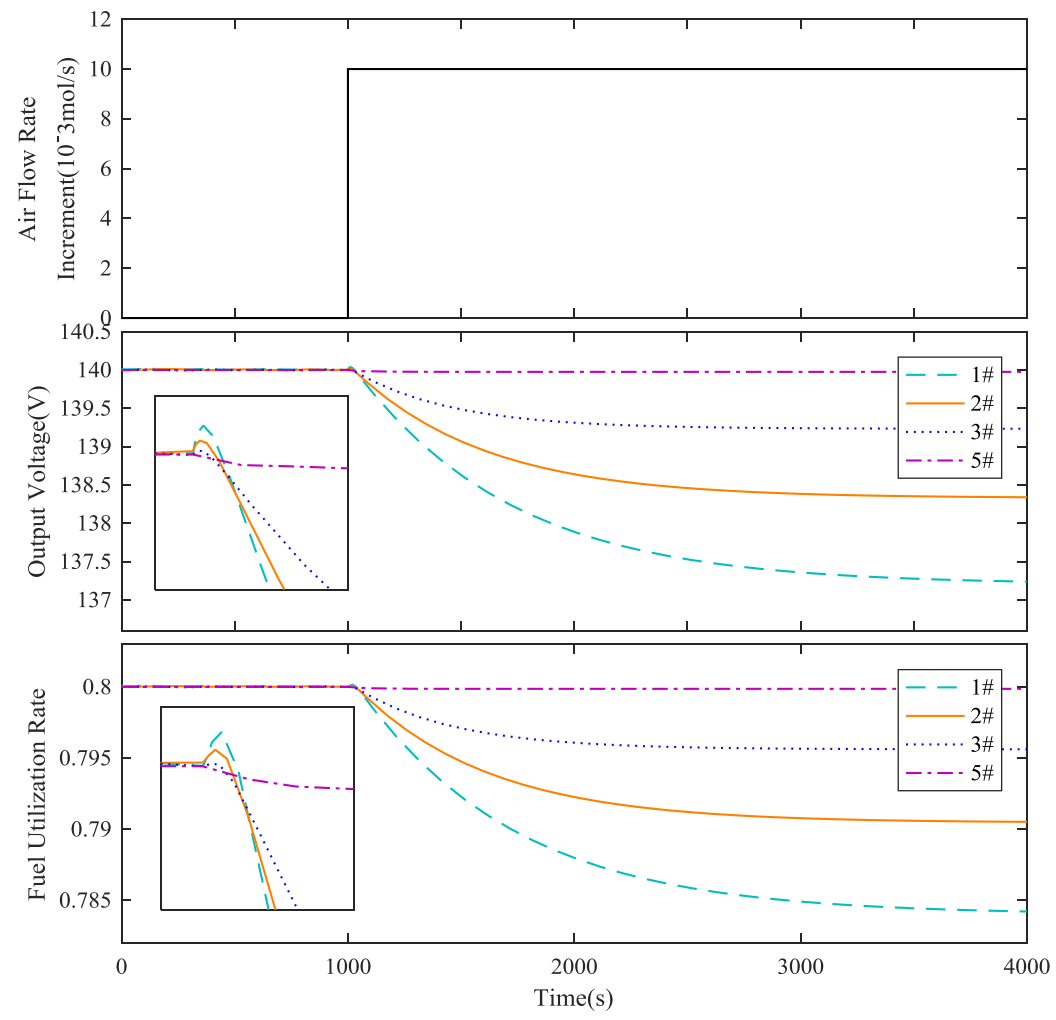

Figure 5. Step response of the SOFC: $10 \times 10^{-3} \mathrm{~mol} / \mathrm{s}$ step increase of air flow rate. 


\section{MFPC Algorithm for SOFC}

As aforementioned, nonlinearity, multivariable coupling and measurable disturbance are main problems in operation of SOFC system, therefore, we propose a novel MFPC to deal with all the issues simultaneously. Schematic diagram of the proposed MFPC is illustrated in Figure 6.

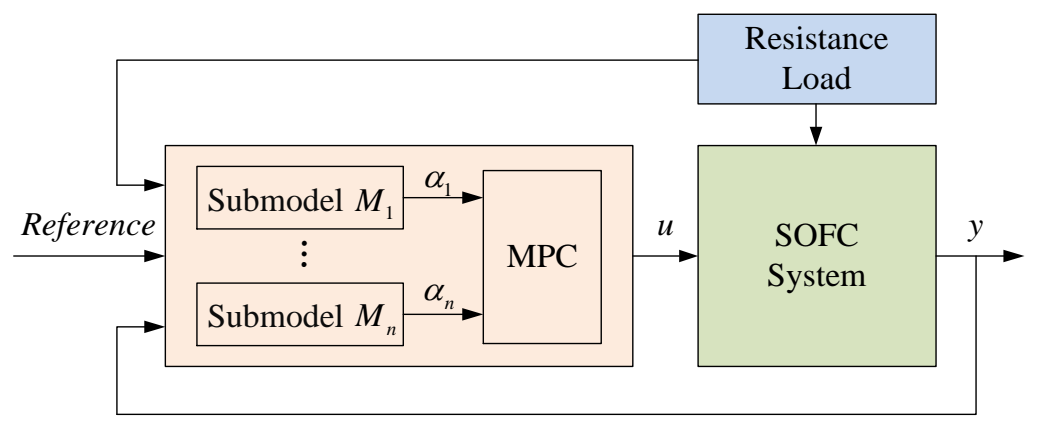

Figure 6. Schematic diagram of the proposed MFPC.

\subsection{Multiple Model Strategy of SOFC}

Generally, model development is the first important step in advanced controller design. In this section, the weighted multiple model strategy is utilized to capture the nonlinear behavior of SOFC system by using combination of several linear sub models.

According to the preceding analysis, the resistance load is chosen to be scheduling variable and four locally linear sub models are developed around operating points 1\#, 2\#, 3\#, 4\#. Firstly, from the step change response tests data in the open-loop in Section 2, the SID [29] method in MATLAB System Identification Toolbox is then adopted to identify the state-space model for these local sub models in continuous time domain. Finally, these state-space models are discretized with sampling time $T_{s}$ to achieve the discrete space-state model for these correspondingly local sub models.

In each computing cycle of MFPC, the weighted sum method is used to complete the weighted multiple model strategy to conquer nonlinearity of SOFC. Specifically, the discrete state-space models of the operating points $1 \# \sim 4 \#$ are served as sub models $\mathrm{M}_{1} \sim \mathrm{M}_{4}$ of the SOFC, then the global model $\mathrm{M}(\mathrm{k})$ of SOFC is calculated according to the formula (10) at the current time $\mathrm{k}$ :

$$
\mathrm{M}(\mathrm{k})=\sum_{\mathrm{i}=1}^{4} \alpha_{\mathrm{i}} \mathrm{M}_{\mathrm{i}}
$$

where $\alpha_{\mathrm{i}}$ is a weight coefficient, specifically, it satisfies the following weight function as resistance load changing as illustrated in Figure 7:

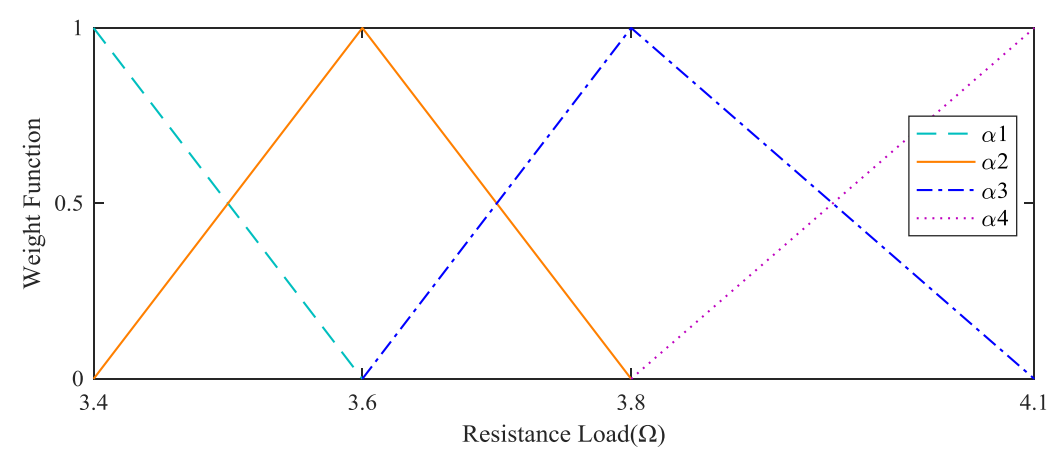

Figure 7. Weight function for the weighted sum method. 
When SOFC goes to the next computing cycle $\mathrm{k}+1$, above steps will be repeated to calculate the global model $\mathrm{M}(\mathrm{k}+1)$ that suitably matches SOFC operating conditions in the next period to complete the calculation to conquer nonlinearity of SOFC.

\subsection{Predictive Model with Feedforward Compensation}

Undoubtedly, the controller is the heart of the entire control system. In this section, a multiple model predictive control with feedforward compensation is designed for the output voltage of SOFC kept $140 \mathrm{~V}$ and the fuel utilization rate of SOFC kept within 0.7 0.9, when resistance load changes.

According to the weighted multiple model method in Section 3.1, the discrete space-state model of the global model $\mathrm{M}(\mathrm{k})$ of SOFC at the current time can be obtained:

$$
\left\{\begin{array}{l}
x_{d}(k+1)=A_{d} x_{d}(k)+B_{u} u(k)+B_{r d} d(k) \\
y_{d}(k)=C_{d} x_{d}(k)
\end{array}\right.
$$

where $\mathrm{x}_{\mathrm{d}}(\mathrm{k})$ is a state variable at the current time $\mathrm{k}, \mathrm{u}(\mathrm{k})$ is a input vector composed of hydrogen flow rate $(\mathrm{mol} / \mathrm{s})$ and air flow rate $(\mathrm{mol} / \mathrm{s}), \mathrm{y}_{\mathrm{d}}(\mathrm{k})$ is a output vector composed of output voltage $(V)$ and fuel utilization rate, $d$ is a resistance load disturbance $(\Omega), A_{d}, B_{u}, B_{r d}, C_{d}$ are coefficient matrixes respectively.

From (11), the following equation holds:

$$
\mathrm{x}_{\mathrm{d}}(\mathrm{k})=\mathrm{A}_{\mathrm{d}} \mathrm{x}_{\mathrm{d}}(\mathrm{k}-1)+\mathrm{B}_{\mathrm{u}} \mathrm{u}(\mathrm{k}-1)+\mathrm{B}_{\mathrm{rd}} \mathrm{d}(\mathrm{k}-1)
$$

we define $\Delta \mathrm{x}_{\mathrm{d}}(\mathrm{k})=\mathrm{x}_{\mathrm{d}}(\mathrm{k})-\mathrm{x}_{\mathrm{d}}(\mathrm{k}-1), \Delta \mathrm{u}(\mathrm{k})=\mathrm{u}(\mathrm{k})-\mathrm{u}(\mathrm{k}-1), \Delta \mathrm{d}(\mathrm{k})=\mathrm{d}(\mathrm{k})-\mathrm{d}(\mathrm{k}-1)$, then from (11) and (12) we can get it:

$$
\Delta \mathrm{x}_{\mathrm{d}}(\mathrm{k}+1)=\mathrm{A}_{\mathrm{d}} \Delta \mathrm{x}_{\mathrm{d}}(\mathrm{k})+\mathrm{B}_{\mathrm{u}} \Delta \mathrm{u}(\mathrm{k})+\mathrm{B}_{\mathrm{rd}} \Delta \mathrm{d}(\mathrm{k})
$$

to associate $\mathrm{y}_{\mathrm{d}}(\mathrm{k}+1)$ with $\Delta \mathrm{x}_{\mathrm{d}}(\mathrm{k})$ :

$$
\begin{aligned}
\Delta \mathrm{y}_{\mathrm{d}}(\mathrm{k}+1) & =\mathrm{y}_{\mathrm{d}}(\mathrm{k}+1)-\mathrm{y}_{\mathrm{d}}(\mathrm{k}) \\
& =\mathrm{C}_{\mathrm{d}} \Delta \mathrm{x}_{\mathrm{d}}(\mathrm{k}+1) \\
& =\mathrm{C}_{\mathrm{d}} \mathrm{A}_{\mathrm{d}} \Delta \mathrm{x}_{\mathrm{d}}(\mathrm{k})+\mathrm{C}_{\mathrm{d}} \mathrm{B}_{\mathrm{u}} \Delta \mathrm{u}(\mathrm{k})+\mathrm{C}_{\mathrm{d}} \mathrm{B}_{\mathrm{rd}} \Delta \mathrm{d}(\mathrm{k})
\end{aligned}
$$

we define a new augmented state variable $x(k)=\left[\Delta x_{d}(k)^{T} y_{d}(k)^{T}\right]^{T}$, the augmented state-space model of global model can be obtained:

$$
\begin{aligned}
& \overbrace{\left[\begin{array}{c}
\Delta x_{d}(k+1) \\
y_{d}(k+1)
\end{array}\right]}^{x(k+1)}=\overbrace{\left[\begin{array}{cc}
A_{d} & O \\
C_{d} A_{d} & I
\end{array}\right]\left[\begin{array}{c}
\Delta x_{d}(k) \\
y_{d}(k)
\end{array}\right]}^{x}+\overbrace{\left[\begin{array}{c}
B_{u} \\
C_{d} B_{u}
\end{array}\right]}^{x} \Delta u(k)+\overbrace{\left[\begin{array}{c}
B_{r d} \\
C_{d} B_{r d}
\end{array}\right]}^{B_{r}} \Delta d(k) \\
& y(k)=\overbrace{\left[\begin{array}{ll}
O & I
\end{array}\right]}^{\text {a }}\left[\begin{array}{c}
\Delta x_{d}(k) \\
y_{d}(k)
\end{array}\right]
\end{aligned}
$$

where $\mathrm{O}$ is a zero matrix, $\mathrm{I}$ is an identity matrix, then:

$$
\left\{\begin{array}{l}
\mathrm{x}(\mathrm{k}+1)=\mathrm{Ax}(\mathrm{k})+\mathrm{B} \Delta \mathrm{u}(\mathrm{k})+\mathrm{B}_{\mathrm{r}} \Delta \mathrm{d}(\mathrm{k}) \\
\mathrm{y}(\mathrm{k})=\mathrm{Cx}(\mathrm{k})
\end{array}\right.
$$

where $\mathrm{A}, \mathrm{B}, \mathrm{B}_{\mathrm{r}}, \mathrm{C}$ are augmented coefficient matrixes respectively. 
Taking the current time $\mathrm{k}$ as starting sampling point, then future augmented state variables can be represented as follows:

$$
\begin{aligned}
\mathrm{x}(\mathrm{k}+1 \mid \mathrm{k})= & \mathrm{Ax}(\mathrm{k})+\mathrm{B} \Delta \mathrm{u}(\mathrm{k})+\mathrm{B}_{\mathrm{r}} \Delta \mathrm{d}(\mathrm{k}) \\
\mathrm{x}(\mathrm{k}+2 \mid \mathrm{k})= & \mathrm{Ax}(\mathrm{k}+1 \mid \mathrm{k})+\mathrm{B} \Delta \mathrm{u}(\mathrm{k}+1 \mid \mathrm{k})+\mathrm{B}_{\mathrm{r}} \Delta \mathrm{d}(\mathrm{k}+1 \mid \mathrm{k}) \\
= & \mathrm{A}^{2} \mathrm{x}(\mathrm{k})+\mathrm{AB} \Delta \mathrm{u}(\mathrm{k})+\mathrm{B} \Delta \mathrm{u}(\mathrm{k}+1)+\mathrm{AB} \mathrm{B}_{\mathrm{r}} \Delta \mathrm{d}(\mathrm{k})+\mathrm{B}_{\mathrm{r}} \Delta \mathrm{d}(\mathrm{k}+1) \\
\mathrm{x}(\mathrm{k}+3 \mid \mathrm{k})= & \mathrm{Ax}(\mathrm{k}+2 \mid \mathrm{k})+\mathrm{B} \Delta \mathrm{u}(\mathrm{k}+2 \mid \mathrm{k})+\mathrm{B}_{\mathrm{r}} \Delta \mathrm{d}(\mathrm{k}+2 \mid \mathrm{k}) \\
= & \mathrm{A}^{3} \mathrm{x}(\mathrm{k})+\mathrm{A}^{2} \mathrm{~B} \Delta \mathrm{u}(\mathrm{k})+\mathrm{AB} \Delta \mathrm{u}(\mathrm{k}+1)+\mathrm{B} \Delta \mathrm{u}(\mathrm{k}+2)+\mathrm{A}^{2} \mathrm{~B}_{\mathrm{r}} \Delta \mathrm{d}(\mathrm{k}) \\
& +\mathrm{AB} \mathrm{B}_{\mathrm{r}} \Delta \mathrm{d}(\mathrm{k}+1)+\mathrm{B}_{\mathrm{r}} \Delta \mathrm{d}(\mathrm{k}+2) \\
\vdots & \\
\mathrm{x}(\mathrm{k}+\mathrm{P} \mid \mathrm{k})= & \mathrm{A}^{\mathrm{P}} \mathrm{x}(\mathrm{k})+\mathrm{A}^{\mathrm{P}-1} \mathrm{~B} \Delta \mathrm{u}(\mathrm{k})+\cdots+\mathrm{A}^{\mathrm{P}-\mathrm{M}} \mathrm{B} \Delta \mathrm{u}(\mathrm{k}+\mathrm{M}-1)+\mathrm{A}^{\mathrm{P}-1} \mathrm{~B}_{\mathrm{r}} \Delta \mathrm{d}(\mathrm{k}) \\
& +\cdots+\mathrm{A}^{\mathrm{P}-\mathrm{M}} \mathrm{B}_{\mathrm{r}} \Delta \mathrm{d}(\mathrm{k}+\mathrm{M}-1)
\end{aligned}
$$

where $\mathrm{P}$ is prediction horizon, $\mathrm{M}$ is control horizon, further, output variables can be described as follows:

$$
\begin{aligned}
& \mathrm{y}(\mathrm{k}+1 \mid \mathrm{k})=\mathrm{CAx}(\mathrm{k})+\mathrm{CB} \Delta \mathrm{u}(\mathrm{k})+\mathrm{CB}_{\mathrm{r}} \Delta \mathrm{d}(\mathrm{k}) \\
& \mathrm{y}(\mathrm{k}+2 \mid \mathrm{k})=\mathrm{CA}^{2} \mathrm{x}(\mathrm{k})+\mathrm{CAB} \Delta \mathrm{u}(\mathrm{k})+\mathrm{CB} \Delta \mathrm{u}(\mathrm{k}+1)+\mathrm{CAB}_{\mathrm{r}} \Delta \mathrm{d}(\mathrm{k})+\mathrm{CB}_{\mathrm{r}} \Delta \mathrm{d}(\mathrm{k}+1) \\
& \mathrm{y}(\mathrm{k}+\mathrm{P} \mid \mathrm{k})=\mathrm{CA}^{\mathrm{P}} \mathrm{x}(\mathrm{k})+\mathrm{CA}^{\mathrm{P}-1} \mathrm{~B} \Delta \mathrm{u}(\mathrm{k})+\cdots+\mathrm{CA}^{\mathrm{P}-\mathrm{M}} \mathrm{B} \Delta \mathrm{u}(\mathrm{k}+\mathrm{M}-1)+\mathrm{CA}^{\mathrm{P}-1} \mathrm{~B}_{\mathrm{r}} \Delta \mathrm{d}(\mathrm{k}) \\
& +\cdots+\mathrm{CA}^{\mathrm{P}-\mathrm{M}^{\mathrm{P}}} \mathrm{B}_{\mathrm{r}} \Delta \mathrm{d}(\mathrm{k}+\mathrm{M}-1)
\end{aligned}
$$

The establishment of formulas (17) and (18) are based on the fact that the resistance disturbance $\mathrm{d}(\mathrm{k})$ is not only measurable but also predictable, but, in fact, for the resistance disturbance $\mathrm{d}(\mathrm{k})$, the current value only can be measured, the future value is unpredictable. In this case, (17) and (18) can be amended as follows:

$$
\begin{aligned}
& \mathrm{x}(\mathrm{k}+1 \mid \mathrm{k})=\mathrm{Ax}(\mathrm{k})+\mathrm{B} \Delta \mathrm{u}(\mathrm{k})+\mathrm{B}_{\mathrm{r}} \Delta \mathrm{d}(\mathrm{k}) \\
& \mathrm{x}(\mathrm{k}+2 \mid \mathrm{k})=\mathrm{A}^{2} \mathrm{x}(\mathrm{k})+\mathrm{AB} \Delta \mathrm{u}(\mathrm{k})+\mathrm{B} \Delta \mathrm{u}(\mathrm{k}+1)+\mathrm{AB}_{\mathrm{r}} \Delta \mathrm{d}(\mathrm{k}) \\
& \mathrm{x}(\mathrm{k}+3 \mid \mathrm{k})=\mathrm{A}^{3} \mathrm{x}(\mathrm{k})+\mathrm{A}^{2} \mathrm{~B} \Delta \mathrm{u}(\mathrm{k})+\mathrm{AB} \Delta \mathrm{u}(\mathrm{k}+1)+\mathrm{B} \Delta \mathrm{u}(\mathrm{k}+2)+\mathrm{A}^{2} \mathrm{~B}_{\mathrm{r}} \Delta \mathrm{d}(\mathrm{k}) \\
& \quad \quad \vdots \\
& \mathrm{x}(\mathrm{k}+\mathrm{P} \mid \mathrm{k})=\mathrm{A}^{\mathrm{P}} \mathrm{x}(\mathrm{k})+\mathrm{A}^{\mathrm{P}-1} \mathrm{~B} \Delta \mathrm{u}(\mathrm{k})+\cdots+\mathrm{A}^{\mathrm{P}-\mathrm{M}} \mathrm{B} \Delta \mathrm{u}(\mathrm{k}+\mathrm{M}-1)+\mathrm{A}^{\mathrm{P}-1} \mathrm{~B}_{\mathrm{r}} \Delta \mathrm{d}(\mathrm{k})
\end{aligned}
$$

further, the output variables are:

$$
\begin{aligned}
& \mathrm{y}(\mathrm{k}+1 \mid \mathrm{k})=\mathrm{CAx}(\mathrm{k})+\mathrm{CB} \Delta \mathrm{u}(\mathrm{k})+\mathrm{CB}_{\mathrm{r}} \Delta \mathrm{d}(\mathrm{k}) \\
& \mathrm{y}(\mathrm{k}+2 \mid \mathrm{k})=\mathrm{CA}^{2} \mathrm{x}(\mathrm{k})+\mathrm{CAB} \Delta \mathrm{u}(\mathrm{k})+\mathrm{CB} \Delta \mathrm{u}(\mathrm{k}+1)+\mathrm{CAB}_{\mathrm{r}} \Delta \mathrm{d}(\mathrm{k}) \\
& \quad \vdots \\
& \mathrm{y}(\mathrm{k}+\mathrm{P} \mid \mathrm{k})=\mathrm{CA}^{\mathrm{P}} \mathrm{x}(\mathrm{k})+\mathrm{CA}^{\mathrm{P}-1} \mathrm{~B} \Delta \mathrm{u}(\mathrm{k})+\cdots+\mathrm{CA}^{\mathrm{P}-\mathrm{M}} \mathrm{B} \Delta \mathrm{u}(\mathrm{k}+\mathrm{M}-1)+\mathrm{CA}^{\mathrm{P}-1} \mathrm{~B}_{\mathrm{r}} \Delta \mathrm{d}(\mathrm{k})
\end{aligned}
$$

The future output vector and corresponding manipulated vector are described as follows:

$$
\begin{aligned}
\mathrm{Y}(\mathrm{k}) & =\left[\begin{array}{llll}
\mathrm{y}(\mathrm{k}+1 \mid \mathrm{k}) & \mathrm{y}(\mathrm{k}+2 \mid \mathrm{k}) & \cdots & \mathrm{y}(\mathrm{k}+\mathrm{P} \mid \mathrm{k})
\end{array}\right]^{\mathrm{T}} \\
\Delta \mathrm{U} & =\left[\begin{array}{llll}
\Delta \mathrm{u}(\mathrm{k}) & \Delta \mathrm{u}(\mathrm{k}+1) & \cdots & \Delta \mathrm{u}(\mathrm{k}+\mathrm{M}-1)
\end{array}\right]^{\mathrm{T}}
\end{aligned}
$$

therefore, the prediction model can be got as follows:

$$
\mathrm{Y}=\mathrm{Fx}(\mathrm{k})+\Phi \Delta \mathrm{U}+\Gamma \Delta \mathrm{d}(\mathrm{k})
$$


where:

$$
\begin{gathered}
\mathrm{F}=\left[\begin{array}{c}
\mathrm{CA} \\
\mathrm{CA}^{2} \\
\vdots \\
\mathrm{CA}^{\mathrm{P}}
\end{array}\right], \quad \Phi=\left[\begin{array}{cccc}
\mathrm{CB} & 0 & \cdots & 0 \\
\mathrm{CAB} & \mathrm{CB} & \cdots & 0 \\
\vdots & \vdots & \ddots & \vdots \\
\mathrm{CA}^{\mathrm{P}-1} \mathrm{~B} & \mathrm{CA}^{\mathrm{P}-2} \mathrm{~B} & \cdots & \mathrm{CA}^{\mathrm{P}-\mathrm{M}_{\mathrm{B}}}
\end{array}\right] \\
\Gamma=\left[\mathrm{CB}_{\mathrm{r}} \mathrm{CAB}_{\mathrm{r}} \cdots \mathrm{CA}^{\mathrm{P}-1} \mathrm{~B}_{\mathrm{r}}\right]
\end{gathered}
$$

According to above calculation, the prediction model (23) that is based on the global model $\mathrm{M}(\mathrm{k})$ (10) is able to capture the SOFC operating behavior in a wide-range to meet the control requirements. Because it is impossible to obtain the prior information for resistance disturbance value of future time, for this reason, the prediction model (23) can be adopted when the prediction horizon $\mathrm{P}>1$, which suggests that we assume the resistance disturbance $\mathrm{d}(\mathrm{k})$ remain constant. This assumption may be out of step with reality, therefore, the control law based on the prediction model (23) may not be optimal. But the deduced control laws still outperform the control law that totally takes no account of feedforward compensation. In addition, a way of the increment of manipulated variables is adopted in prediction model (23), which is equivalent to introduce an integrating factor that can effectively eliminate steady-state deviation and accomplish zero error adjustment.

\subsection{Optimization Performance Index and Constrain}

In the course of actual operation of the SOFC system, the hydrogen flow rate and air flow rate are usually constrained, for example, the response of hydrogen flow rate may be limited by the performance of fuel blower, which is equivalent to constrain $u$ and $\Delta u$. Therefore, out of consideration of these circumstances, the problems that the hydrogen flow rate and air flow rate and their own increment are constrained can be described as an optimization problem. The problem features with that minimize the performance index taking $\Delta \mathrm{U}$ as the optimization variable under the prediction model (23), as follows:

$$
\begin{array}{ll}
\min & \mathrm{J}=\left\|\mathrm{Y}_{\mathrm{r}}-\mathrm{Y}\right\|_{\mathrm{Z}}^{2}+\|\Delta \mathrm{U}\|_{\mathrm{W}}^{2} \\
\text { s.t. } & \mathrm{u}_{\min } \leq \mathrm{u} \leq \mathrm{u}_{\max }, \Delta \mathrm{u}_{\min } \leq \Delta \mathrm{u} \leq \Delta \mathrm{u}_{\max }
\end{array}
$$

where $Y_{r}$ is a reference signal, $\mathrm{Z}$ and $\mathrm{W}$ are error weight matrix and control matrix respectively, further, considering the prediction model (23), the following equation holds:

$$
\min \mathrm{J}=\left\|\mathrm{Y}_{\mathrm{r}}-\mathrm{Fx}(\mathrm{k})-\Phi \Delta \mathrm{U}-\Gamma \Delta \mathrm{d}(\mathrm{k})\right\|_{\mathrm{Z}}^{2}+\|\Delta \mathrm{U}\|_{\mathrm{W}}^{2}
$$

constraint of manipulated variables is expressed as follows:

$$
\begin{gathered}
\mathrm{u}_{\min } \leq \mathrm{u}(\mathrm{k})=\mathrm{u}(\mathrm{k}-1)+\Delta \mathrm{u}(\mathrm{k}) \leq \mathrm{u}_{\max } \\
\mathrm{u}_{\min } \leq \mathrm{u}(\mathrm{k}+1)=\mathrm{u}(\mathrm{k}-1)+\Delta \mathrm{u}(\mathrm{k})+\Delta \mathrm{u}(\mathrm{k}+1) \leq \mathrm{u}_{\max } \\
\vdots \\
\mathrm{u}_{\min } \leq \mathrm{u}(\mathrm{k}+\mathrm{M}-1)=\mathrm{u}(\mathrm{k}-1)+\Delta \mathrm{u}(\mathrm{k})+\cdots+\Delta \mathrm{u}(\mathrm{k}+\mathrm{M}-1) \leq \mathrm{u}_{\max }
\end{gathered}
$$

rewritten as a matrix form:

$$
\mathrm{U}_{\min } \leq \mathrm{S} \Delta \mathrm{U} \leq \mathrm{U}_{\max } \Rightarrow\left[\begin{array}{c}
\mathrm{S} \\
-\mathrm{S}
\end{array}\right] \Delta \mathrm{U} \leq\left[\begin{array}{c}
\mathrm{U}_{\max } \\
-\mathrm{U}_{\min }
\end{array}\right]
$$

where:

$$
\begin{aligned}
\mathrm{U}_{\min } & =\left[\begin{array}{lll}
\mathrm{u}_{\min }-\mathrm{u}(\mathrm{k}-1) & \cdots & \mathrm{u}_{\min }-\mathrm{u}(\mathrm{k}-1)
\end{array}\right]_{1 \times \mathrm{n}_{\mathrm{u}} \cdot \mathrm{M}}^{\mathrm{T}} \\
\mathrm{U}_{\max } & =\left[\begin{array}{lll}
\mathrm{u}_{\max }-\mathrm{u}(\mathrm{k}-1) & \cdots & \mathrm{u}_{\max }-\mathrm{u}(\mathrm{k}-1)
\end{array}\right]_{1 \times \mathrm{n}_{\mathrm{u}} \cdot \mathrm{M}}^{\mathrm{T}}
\end{aligned}
$$




$$
S=\left[\begin{array}{cccc}
\mathrm{I} & & & \\
\mathrm{I} & \mathrm{I} & & \\
\vdots & \vdots & \ddots & \\
\mathrm{I} & \mathrm{I} & \cdots & \mathrm{I}
\end{array}\right]_{\mathrm{M} \times \mathrm{M}}
$$

where $n_{u}$ is the number of manipulated variables, $I$ is a $n_{u} \times n_{u}$ identity matrix. Constraint of manipulated variables increment can be expressed as:

$$
\Delta \mathrm{u}_{\min } \leq \Delta \mathrm{u} \leq \Delta \mathrm{u}_{\max }
$$

Namely

$$
\Delta \mathrm{U}_{\min } \leq \Delta \mathrm{U} \leq \Delta \mathrm{U}_{\max }
$$

where:

$$
\begin{aligned}
\Delta \mathrm{U}_{\min } & =\left[\begin{array}{lll}
\Delta \mathrm{u}_{\min } & \cdots & \Delta \mathrm{u}_{\min }
\end{array}\right]_{1 \times \mathrm{n}_{\mathrm{u}} \cdot \mathrm{M}}^{\mathrm{T}} \\
\Delta \mathrm{U}_{\max } & =\left[\begin{array}{lll}
\Delta \mathrm{u}_{\max } & \cdots & \Delta \mathrm{u}_{\max }
\end{array}\right]_{1 \times \mathrm{n}_{\mathrm{u}} \cdot \mathrm{M}}^{\mathrm{T}}
\end{aligned}
$$

then the final performance index is put forward as follows:

$$
\begin{gathered}
\min \mathrm{J}=\left\|\mathrm{Y}_{\mathrm{r}}-\mathrm{Fx}(\mathrm{k})-\Phi \Delta \mathrm{U}-\Gamma \Delta \mathrm{d}(\mathrm{k})\right\|_{\mathrm{Z}}^{2}+\|\Delta \mathrm{U}\|_{\mathrm{W}}^{2} \\
\text { s.t. }\left[\begin{array}{c}
\mathrm{S} \\
-\mathrm{S}
\end{array}\right] \quad \Delta \mathrm{U} \leq\left[\begin{array}{c}
\mathrm{U}_{\max } \\
-\mathrm{U}_{\min }
\end{array}\right] \\
\Delta \mathrm{U}_{\min } \leq \Delta \mathrm{U} \leq \Delta \mathrm{U}_{\max }
\end{gathered}
$$

thus, to solve optimal manipulated variables can be transformed into a solving problem for quadratic programs, it is more convenient for MFPC algorithm for SOFC to be practical application.

\subsection{Feedback Correction}

A Kalman filter is adopted to accomplish a state estimation that is as a state correction to overcome the influence of uncertainty, such as system modeling errors and unknown disturbances to the control system. At the current time $k$, the following calculation is made according to Kalman filter principle.

The augmented state correction of SOFC at current time $\mathrm{k}$ can be calculated as follows:

$$
\mathrm{x}(\mathrm{k} \mid \mathrm{k})=\mathrm{x}(\mathrm{k} \mid \mathrm{k}-1)+\mathrm{K}_{\mathrm{g}}(\mathrm{k})\left(\mathrm{Y}_{\mathrm{m}}(\mathrm{k})-\mathrm{Cx}(\mathrm{k} \mid \mathrm{k}-1)\right)
$$

where $x(k \mid k)$ represents an augmented state correction for the current time $k$ that is adopted as an optimal augmented state estimation, $\mathrm{Y}_{\mathrm{m}}(\mathrm{k})$ represents the measured value of the actual output of SOFC system, $x(k \mid k-1)$ represents an augmented state estimation for the time $k$ at the time $k-1$ and can be calculated as formula (37), $\mathrm{K}_{\mathrm{g}}(\mathrm{k})$ is the Kalman gain for the current time and can be calculated as formula (38):

$$
\mathrm{x}(\mathrm{k} \mid \mathrm{k}-1)=\mathrm{Ax}(\mathrm{k}-1 \mid \mathrm{k}-1)+\mathrm{B} \Delta \mathrm{u}(\mathrm{k}-1)+\mathrm{B}_{\mathrm{r}} \Delta \mathrm{d}(\mathrm{k}-1)
$$

where $\mathrm{x}(\mathrm{k}-1 \mid \mathrm{k}-1)=\mathrm{x}(\mathrm{k}-1)$ represents an augmented state update for the previous time;

$$
\mathrm{K}_{\mathrm{g}}(\mathrm{k})=\mathrm{P}(\mathrm{k} \mid \mathrm{k}-1) \mathrm{C}^{\mathrm{T}} /\left(\mathrm{C}^{\mathrm{T}} \mathrm{P}(\mathrm{k} \mid \mathrm{k}-1)+\mathrm{R}\right)
$$

where $\mathrm{R}$ represents a noise covariance matrix, $\mathrm{P}(\mathrm{k} \mid \mathrm{k}-1)$ represents a covariance matrix estimation for the time $k$ at the time $k-1$ and can be calculated as follows:

$$
\mathrm{P}(\mathrm{k} \mid \mathrm{k}-1)=\mathrm{AP}(\mathrm{k}-1 \mid \mathrm{k}-1) \mathrm{A}^{\mathrm{T}}+\mathrm{Q}
$$


where $\mathrm{P}(\mathrm{k}-1 \mid \mathrm{k}-1)$ represents a covariance matrix correction for the previous time, $\mathrm{Q}$ is a disturbance covariance matrix. The covariance matrix correction for the current time $\mathrm{k} P(\mathrm{k} \mid \mathrm{k})$ can be calculated as follows:

$$
\mathrm{P}(\mathrm{k} \mid \mathrm{k})=\left(\mathrm{I}-\mathrm{K}_{\mathrm{g}}(\mathrm{k}) \mathrm{C}\right) \mathrm{P}(\mathrm{k} \mid \mathrm{k}-1)
$$

where I is an identity matrix.

In this way, the optimal augmented state estimation of SOFC for the current time $x(k \mid k)$ can be obtained. Then we substitute $x(k)=x(k \mid k)$ into the prediction model (23) as the initial value of the augmented state variable and complete the augmented state update at next time. Meanwhile, the covariance matrix correction can be completed to prepare for next calculation and aforementioned steps will be repeated when the next calculation cycle comes. In fact, this process is equivalent to a feedback correction of the augmented state variable of SOFC to compensate for uncertainty caused by modeling errors and disturbances.

\section{Simulation Results}

In this section, the MFPC is employed to control the SOFC system to satisfy requirements that output voltage is $140 \mathrm{~V}$ and fuel utilization rate is within a safe range $0.7 \sim 0.9$, when resistance load changes in a wide-range and the air flow rate or hydrogen flow rate channel disturbance occurs. Furthermore, influence of reforming hydrocarbon fuel is considered in the last simulation case. For comparison purpose, the proposed MFPC is compared with a single model based feedforward predictive control (SFPC) that is designed based on the prediction model (23) from the single discrete state-space model of operating point $1 \#$ in simulation. The tuning parameters of the controllers for the SOFC are listed Table 3.

Table 3. The tuning parameters of the controllers.

\begin{tabular}{cc}
\hline Parameter & Value \\
\hline $\mathrm{T}_{\mathrm{s}}$ & $20 \mathrm{~s}$ \\
$\mathrm{P}$ & 30 \\
$\mathrm{M}$ & 20 \\
$\mathrm{n}_{\mathrm{u}}$ & 2 \\
$\mathrm{Z}$ & $\operatorname{diag}[40,550]$ \\
$\mathrm{W}$ & $\operatorname{diag}[10,1]$ \\
$\mathrm{u}_{\max }$ & {$[25,200]^{\mathrm{T}}$} \\
$\mathrm{u}_{\min }$ & {$[1,3]^{\mathrm{T}}$} \\
$\Delta \mathrm{u}_{\max }$ & {$[0.03,50]^{\mathrm{T}}$} \\
$\Delta \mathrm{u}_{\min }$ & {$[-0.03,-50]^{\mathrm{T}}$} \\
\hline
\end{tabular}

\subsection{Case 1}

The first case is designed for the intention to test the control performance of the controllers when the resistance load step change in a wide-range. We suppose that the SOFC system is operation at steady-state operating point $1 \#$ at the start of simulation, then the resistance load return $3.4 \Omega$ after experiencing a series of resistance load step change in a wide-range and the period of resistance load change is assumed be $2500 \mathrm{~s}$, the results are shown in Figures 8-10.

From the simulation results, first of all, the hydrogen flow rate and fuel utilization rate change rapidly due to its dynamic characteristics, when the outside resistance load changes. And it is obvious that the proposed MFPC is similar to SFPC when the SOFC operating point is near the operating point $1 \#$ that is used to design SFPC. However, as resistance load changing in a wide-range, especially when the actual operating point of SOFC is far away from the operating point $1 \#$, the prediction model from the single operating point $1 \#$ gradually deviates the actual operating conditions of SOFC, which results in the question of model mismatch and the incorrect augmented state correction of SFPC. In this case, SFPC cannot capture the nonlinear behavior and operating conditions of SOFC, which 
leads to SFPC controller to make inappropriate manipulated variables by solving the optimization performance index, so the sharp oscillation of output voltage and fuel utilization rate of the SOFC system occur. On the contrary, because the multiple model strategy that is based on four operating points can always obtain a suitable augmented state correction (36) and correct prediction model (23) that matches the operating conditions of SOFC, the proposed MFPC controller can subtly capture the nonlinearity of SOFC and track the actual operating conditions of SOFC in a wide-range. Then the MFPC in operating range always makes an effective control action and always maintains a brilliant control effect by solving the optimization performance index (31), which is demonstrated by the facts that the output voltage of SOFC quickly returns to the set point and fuel utilization rate is always within $0.7 \sim 0.9$, the transient process is relatively smooth and the SOFC reaches stead state quickly, when resistance disturbance occur in a wide-range.

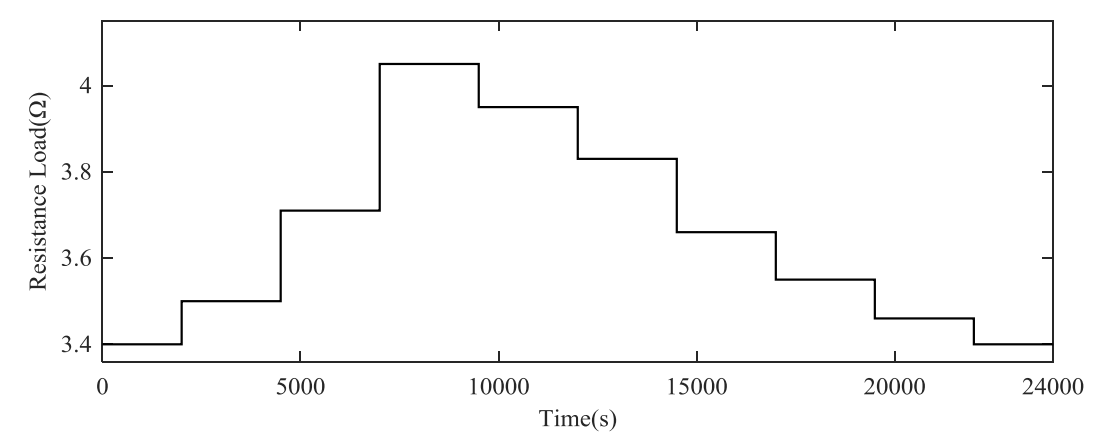

Figure 8. Case 1: Resistance load variation.

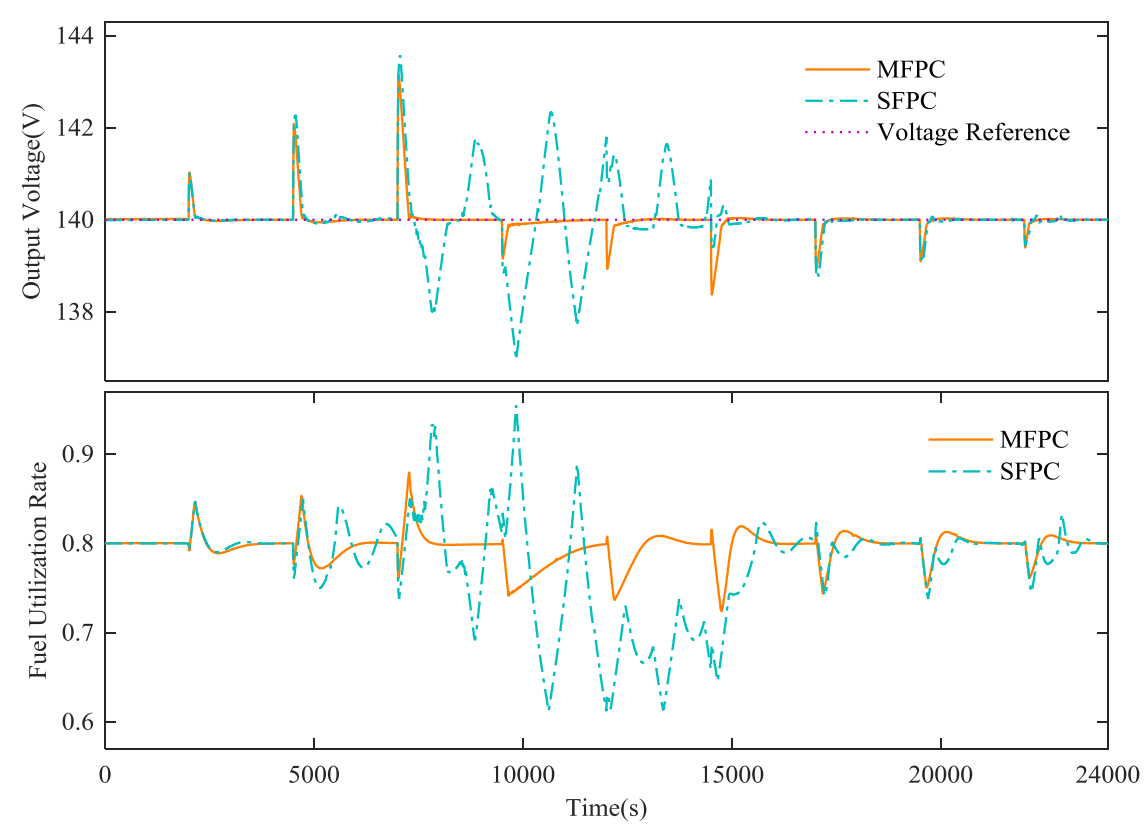

Figure 9. Case 1: Performance of the SOFC: output variables. 


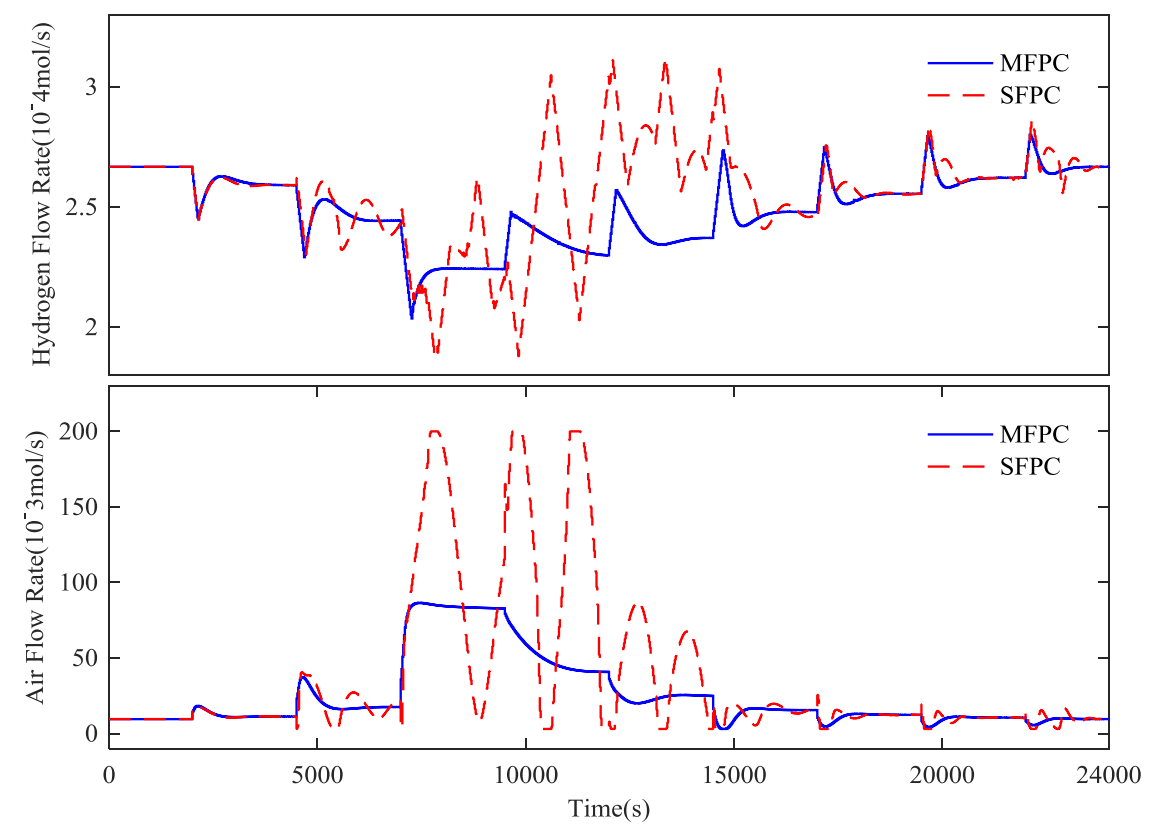

Figure 10. Case 1: Performance of the SOFC: manipulated variables.

\subsection{Case 2}

The second case is presented for the purpose of that tests the disturbance rejection performance of the controllers. We suppose that at the beginning of the test, the system is operation at steady-state operating point $3 \#$ and the resistance load is always maintained as a constant value $3.8 \Omega$ in simulation, then the hydrogen flow rate channel occur $0.4 \times 10^{-4} \mathrm{~mol} / \mathrm{s}$ step increase disturbance at $1000 \mathrm{~s}$, subsequently, the air flow rate channel occur $15 \times 10^{-3} \mathrm{~mol} / \mathrm{s}$ step increase disturbance at $1500 \mathrm{~s}$, the results are shown in Figures 11 and 12.

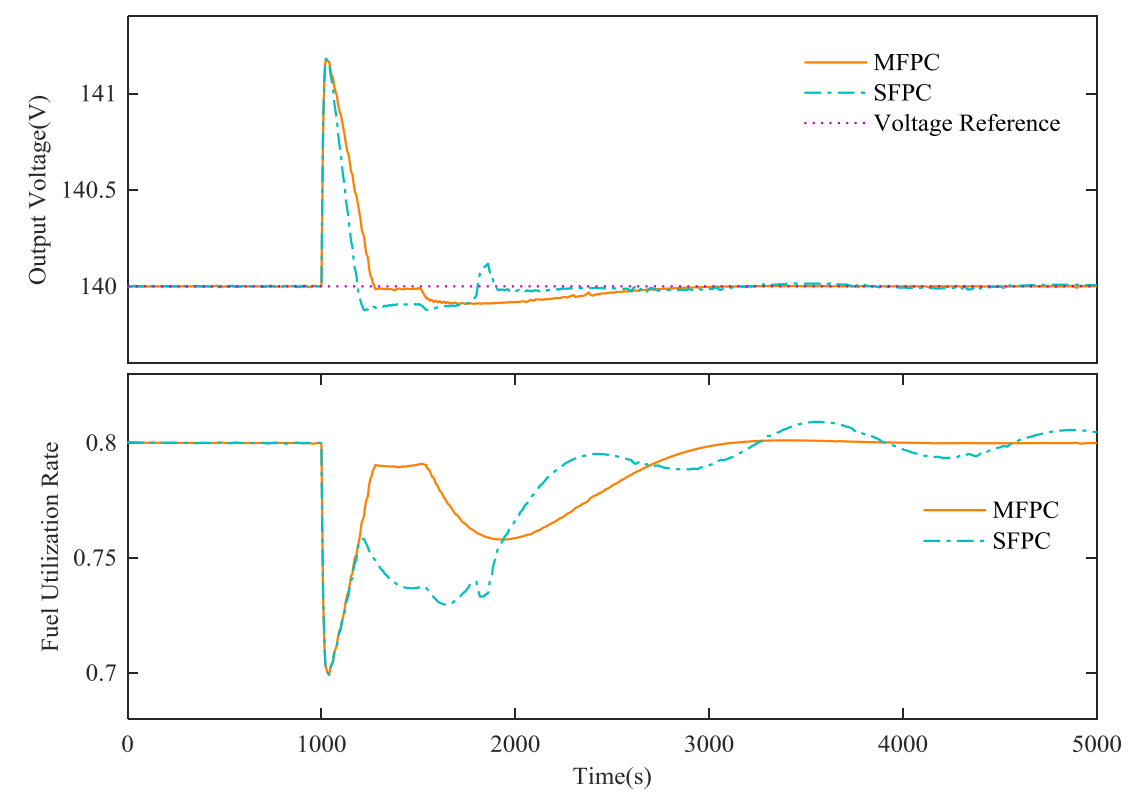

Figure 11. Case 2: Performance of the SOFC: output variables. 


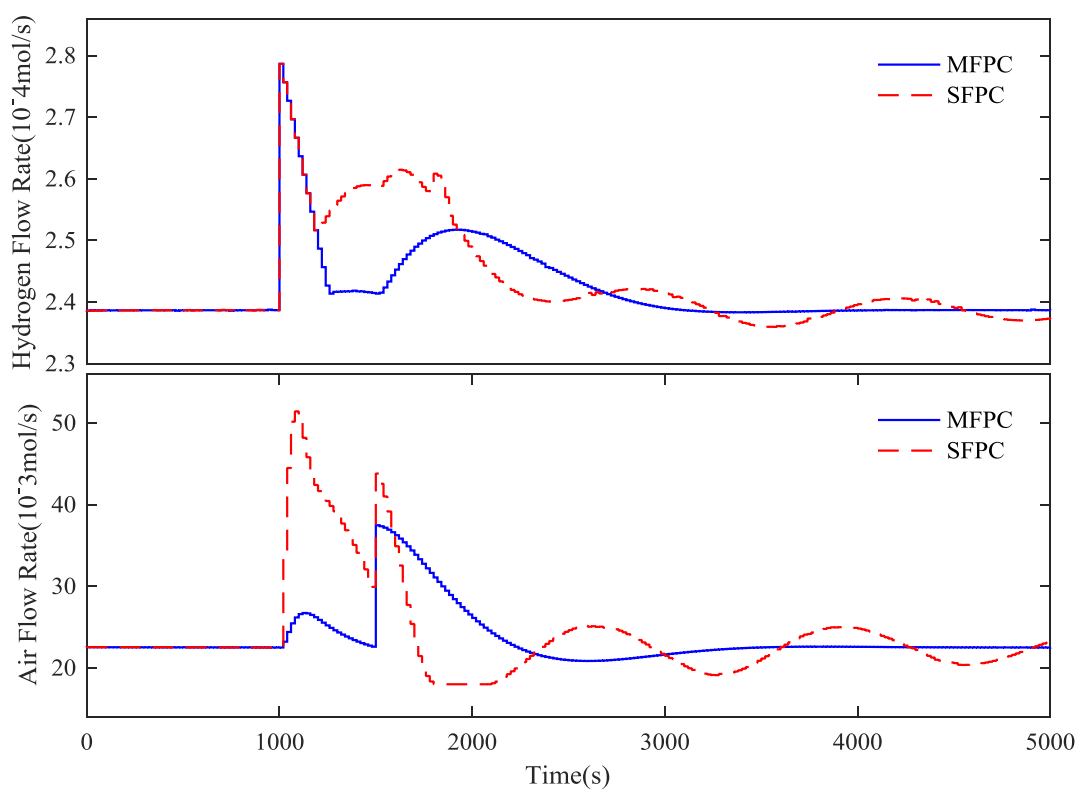

Figure 12. Case 2: Performance of the SOFC: manipulated variables.

According to simulation results illustrated in above figures, it is not difficult to find that the proposed MFPC is clearly superior to SFPC when the hydrogen or air flow rate disturbance occurs in the test. It should be noticed that when the hydrogen and air flow rate are step increase at $1000 \mathrm{~s}$ and $1500 \mathrm{~s}$ respectively, because of its dynamics, the output voltage and fuel utilization rate of the SOFC both show a sharp change. In the same way, after the disturbance occurring, because the augmented state correction (36) and the prediction model (23) that are based on the multiple model strategy, the proposed MFPC can capture these changes keenly, which results in an accurate move of manipulated variables by solving the right optimization performance index (31), so the output voltage and fuel utilization rate return desired value quickly, smoothly and eventually reach steady-state. Meanwhile, a large overshoot and oscillation are produced under SFPC due to the aforementioned model mismatch that make mistake manipulated variables, so the SFPC is hard to meet the operating requirements of SOFC and cannot ever reach steady-state.

\subsection{Case 3}

Because sometimes it is necessary for SOFC to implement a pretreatment for the raw fuel to produce hydrogen, for instance, natural gas is used to produce hydrogen by method of reforming hydrocarbon as depicted by the dot-dash line in Figure 2. Therefore, the last case is designed for the consideration of influence of fuel processing to the controller. In the last case, the dynamic model of reforming hydrocarbon is cited from [9] and added to the dynamic model of SOFC. The dynamic model of reforming hydrocarbon is a one order inertial link and cascades to hydrogen flow rate channel and its transfer function is expressed as follows:

$$
\mathrm{G}_{\mathrm{r}}=\frac{1}{1+\tau \mathrm{s}}
$$

where $\tau=5$.

Then the case 1 and case 2 are reproduced to verify the control performance of the proposed MFPC with the same controller parameters under the influence of reforming hydrocarbon and it should be noted that as the control plant has changed, so we need to identify the state-space models of object at different operating points to get the correct $\mathrm{M}(\mathrm{k})(10)$ as aforementioned in Section 3.1. The simulation results are shown in Figures 13-17. 


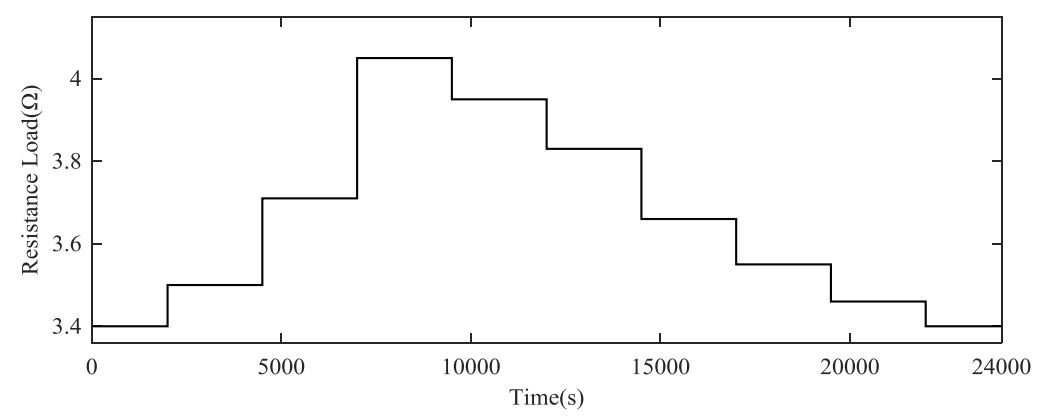

Figure 13. Case 3: Reproducing case 1 with the reforming hydrocarbon, resistance load variation.

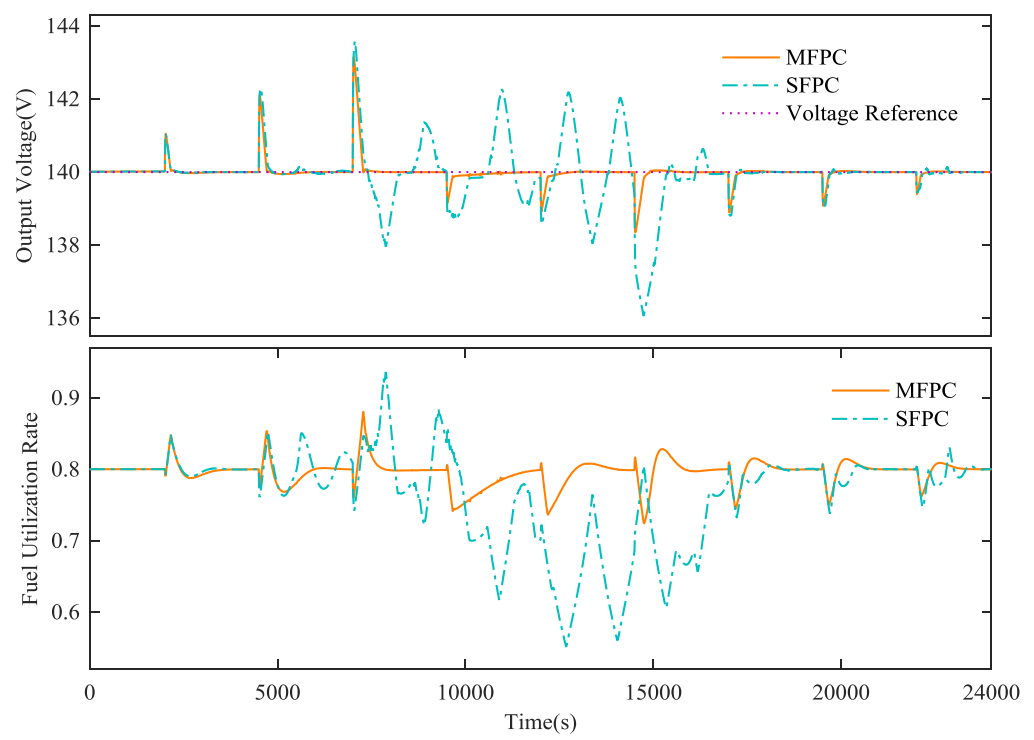

Figure 14. Case 3: Reproducing case 1 with the reforming hydrocarbon, performance of the SOFC: output variables.

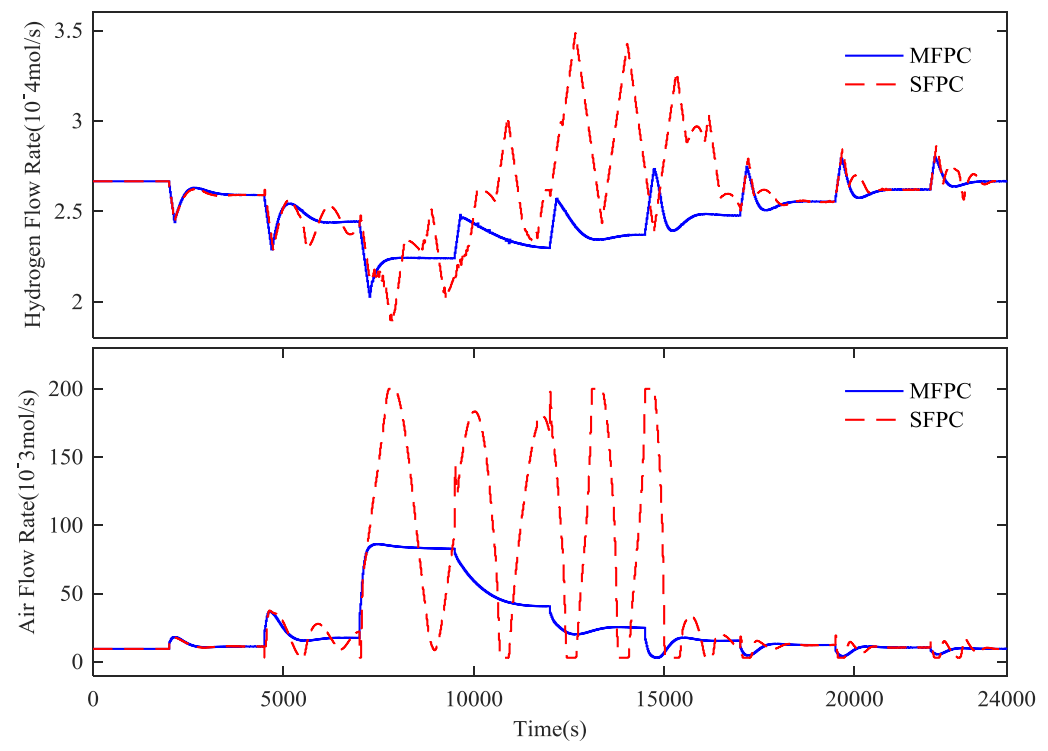

Figure 15. Case 3: Reproducing case 1 with the reforming hydrocarbon, performance of the SOFC: manipulated variables. 


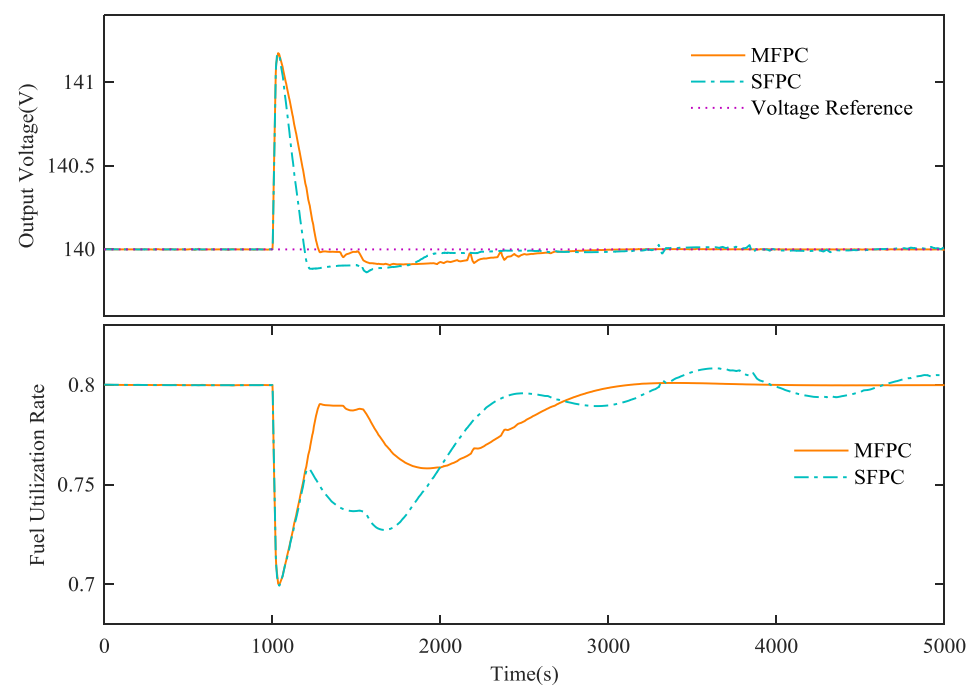

Figure 16. Case 3: Reproducing case 2 with the reforming hydrocarbon, performance of the SOFC: output variables.

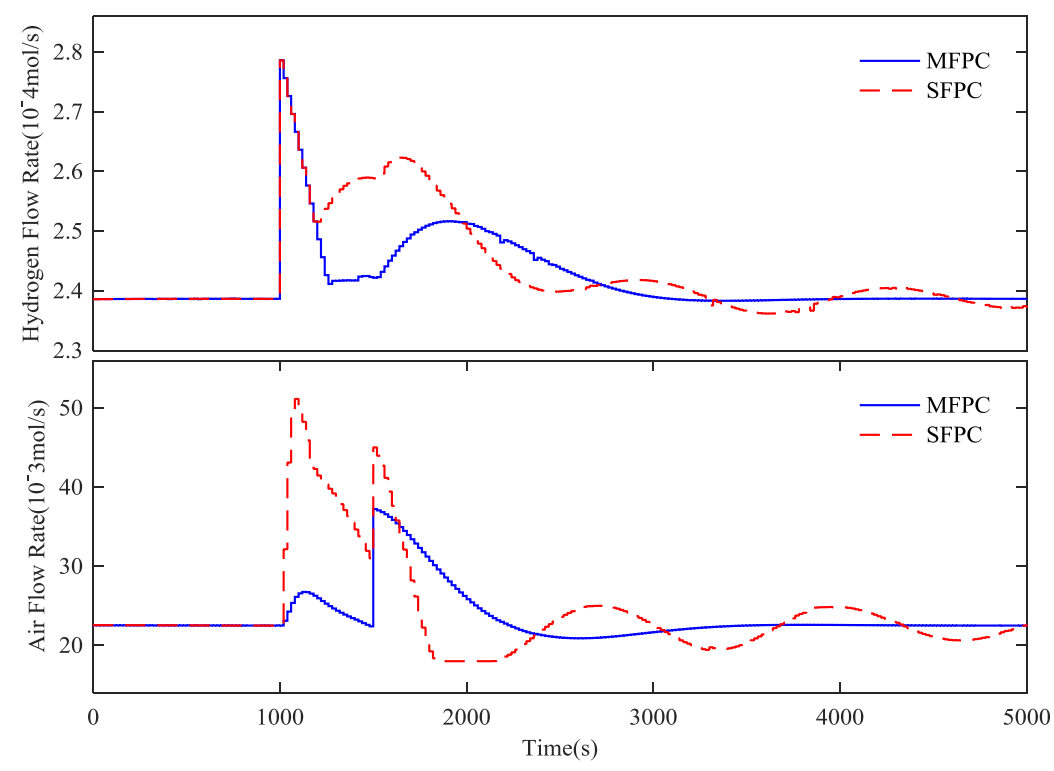

Figure 17. Case 3: Reproducing case 2 with the reforming hydrocarbon, performance of the SOFC: manipulated variables.

By comparing the simulation results of the case 3 with the simulation results of the case 1 and case 2, we can clearly find that the simulation results of case 3 are very similar to the results of case 1 and case 2, which demonstrates that the performance of the proposed MFPC is hardly influenced by the hydrocarbon reforming process and the proposed MFPC still maintains a favorable control effect, on the contrary.

\section{Conclusions}

Considering the operation of SOFC system, the nonlinearity, multivariable coupling and measurable disturbance are main problems. In this regard, this paper proposes an MFPC approach to overcome these problems simultaneously. Firstly, the multiple model strategy of SOFC system is developed by use of the weighted sum of several linear sub models to conquer the nonlinearity. Secondly, state-space based MPC with feedforward compensation is adopted to surmount the problems of multivariable coupling and measurable disturbance. Moreover, the constraints of manipulated 
variables in practical application of SOFC is taken into account and is solved by use of the quadratic programming and the Kalman filter is adopted to accomplish state correction. Finally, the simulation results indicate that the proposed MFPC have capacity to effectively overcome the problems of nonlinearity and multivariable coupling of the SOFC system and have capacity to achieve a rapid and accurate adjustment, the robustness of the proposed controller is strong and the excellent control effect for requirements of SOFC is achieved. The work we have done effectively solves the control problem of SOFC under the constant output voltage mode, and we supply a supplementary material for readers that includes the data and related programs in the article, which will contribute to promotion and safe application of SOFC.

Supplementary Materials: The MATLAB/SIMULINK files are available online at http://www.mdpi.com/20711050/10/2/437/s1.

Acknowledgments: This work was supported by the Natural Science Foundation of Jiangsu Province, China under Grant BK20170686, National Key Technology R\&D Program under Grant 2016YFB0600201 and the open funding of the state key lab for power systems, Tsinghua University.

Author Contributions: All authors collectively conceived the research and carried out the analysis. L.W. led the simulation and paper writing with contributions and guidance from L.S., J.S. and Q.H.

Conflicts of Interest: The authors declare no conflict of interest.

\section{References}

1. Dai, A.N.; Xu, L.F.; Shui, A.Z. Research Progress of Solid Oxide Fuel Cell. Bull. Chin. Ceram. Soc. 2015, 34, 234-238.

2. Liu, X.L.; Ma, J. The development of Solid Oxide Fuel Cell Materials. Bull. Chin. Ceram. Soc. 2001, 20, 24-29.

3. Lukas, M.D.; Lee, K.Y.; Ghezel-Ayagh, H. Development of a stack simulation model for control study on direct reforming molten carbonate fuel cell power plant. IEEE Trans. Energy Convers. 1999, 14, 1651-1657. [CrossRef]

4. Lukas, M.D.; Lee, K.Y.; Ghezel-Ayagh, H. Modeling and cycling control of carbonate fuel cell power plants. Control Eng. Pract. 2002, 10, 197-206. [CrossRef]

5. Cruz Rojas, A.; Lopez Lopez, G.; Gomez-Aguilar, J.F.; Alvarado, V.M.; Sandoval Torres, C.L. Control of the Air Supply Subsystem in a PEMFC with Balance of Plant Simulation. Sustainability 2017, 9, 73. [CrossRef]

6. Huang, Z. Fuel Cell and Applications; Electronics Industry Press: Beijing, China, 2005.

7. Buonomano, A.; Calise, F.; d'Accadia, M.D.; Palombo, A.; Vicidomini, M. Hybrid solid oxide fuel cells-gas turbine systems for combined heat and power: A review. Appl. Energy 2015, 156, 32-85. [CrossRef]

8. Suther, T.; Fung, A.; Koksal, M.; Zabihian, F. Macro Level Modeling of a Tubular Solid Oxide Fuel Cell. Sustainability 2010, 2, 3549-3560. [CrossRef]

9. Sun, L.; Wu, G.; Xue, Y.; Shen, J.; Li, D.; Lee, K.Y. Coordinated Control Strategies for SOFC Power Plant in a Microgrid. IEEE Trans. Energy Convers. 2017, PP, 1. [CrossRef]

10. Singhal, S.C.; Kendall, K. High-Temperature Solid Oxide Fuel Cells: Fundamentals, Design and Applications; Elsevier: Amsterdam, The Netherland, 2002.

11. Angrisani, G.; Roselli, C.; Sasso, M. Distributed microtrigeneration systems. Prog. Energy Combust. Sci. 2012, 38, 502-521. [CrossRef]

12. Chicco, G.; Mancarella, P. Distributed multi-generation: A comprehensive view. Renew. Sustain. Energy Rev. 2009, 13, 535-551. [CrossRef]

13. Zhao, F.; Zhang, C.H.; Sun, B.; Wei, D. Three-stage collaborative global optimization design mothod of combined cooling heating and power. Proc. CSEE 2015, 35, 3785-3793.

14. Zhang, T.; Zhu, T.; Gao, N.; Wu, Z. Optimization design multi-criteria comprehensive evaluation method of combined cooling heating and power system. Proc. CSEE 2015, 35, 3706-3713.

15. Ning-Sheng, C.A.; Chen, L.; Yi-Xiang, S.H. Research and development of solid oxide direct carbon fuel cell. Proc. CSEE 2011, 31, 112-120.

16. Yu, Z.; Men, Q.; Zhang, C.; Han, J. Performance Analysis of the Near Zero $\mathrm{CO}_{2}$ Emissions Tri-generation System Based on Solid Oxide Fuel Cell Cycle. Proc. CSEE 2017, 37, 200-208. 
17. Kang, Y.W.; Cao, G.Y.; Tu, Y.Y.; Li, J. Output Voltage Feedforward-Feedback Control of Solid Oxide Fuel Cells. J. Eng. Therm. Energy Power 2008, 23, 97-101.

18. Sun, L.; Li, D.; Wu, G.; Lee, K.Y.; Xue, Y. A Practical Compound Controller Design for Solid Oxide Fuel Cells. IFAC-PapersOnLine 2015, 48, 445-449. [CrossRef]

19. Sun, L.; Hua, Q.; Shen, J.; Xue, Y.; Li, D.; Lee, K.Y. A Combined Voltage Control Strategy for Fuel Cell. Sustainability 2017, 9, 1517. [CrossRef]

20. Li, Y.H.; Choi, S.S.; Rajakaruna, S. An analysis of the control and operation of a solid oxide fuel-cell power plant in an isolated system. IEEE Trans. Energy Convers. 2005, 20, 381-387. [CrossRef]

21. Padulles, J.; Ault, G.W.; McDonald, J.R. An integrated SOFC plant dynamic model for power systems simulation. J. Power Sources 2000, 86, 495-500. [CrossRef]

22. Wang, C.; Nehrir, M.H. A Physically Based Dynamic Model for Solid Oxide Fuel Cells. IEEE Trans. Energy Convers. 2007, 22, 887-897. [CrossRef]

23. Gao, F.; Simoes, M.G.; Blunier, B.; Miraoui, A. Development of a Quasi 2-D Modeling of Tubular Solid-Oxide Fuel Cell for Real-Time Control. IEEE Trans. Energy Convers. 2014, 29, 9-19. [CrossRef]

24. Bayati, M.; Abedi, M.; Gharehpetian, G.B. A new control system for grid-feeding power converters of solid oxide fuel cells. In Proceedings of the Iranian Conference on Electrical Engineering, Tehran, Iran, 2-4 May 2017; pp. 961-966.

25. Hayati, M.R.; Khayatian, A.; Dehghani, M. Simultaneous Optimization of Net Power and Enhancement of PEM Fuel Cell Lifespan Using Extremum Seeking and Sliding Mode Control Techniques. IEEE Trans. Energy Convers. 2016, 31, 688-696. [CrossRef]

26. Lan, T.; Strunz, K. Multi-Physics Transients Modeling of Solid Oxide Fuel Cells: Methodology of Circuit Equivalents and Use in EMTP-type Power System Simulation. IEEE Trans. Energy Convers. 2017, PP, 1.

27. Yu, S.; Fernando, T.; Chau, T.K.; Iu, H.H. Voltage Control Strategies for Solid Oxide Fuel Cell Energy System Connected to Complex Power Grids Using Dynamic State Estimation and STATCOM. IEEE Trans. Power Syst. 2016, $P$ P , 1. [CrossRef]

28. Yu, S.; Fernando, T.; Iu, H.H. A Comparison Study for the Estimation of SOFC Internal Dynamic States in Complex Power Systems Using Filtering Algorithms. IEEE Trans. Ind. Inform. 2017, PP, 1. [CrossRef]

29. Van Overschee, P.; De Moor, B.L. Subspace Identification for Linear Systems; Springer Science \& Business Media: Berlin, Germany, 1996.

(C) 2018 by the authors. Licensee MDPI, Basel, Switzerland. This article is an open access article distributed under the terms and conditions of the Creative Commons Attribution (CC BY) license (http://creativecommons.org/licenses/by/4.0/). 